\title{
UNDERSTANDING THE CORRELATION BETWEEN ALZHEIMER'S DISEASE POLYGENIC RISK, WEALTH, AND THE COMPOSITION OF WEALTH HOLDINGS
}

\author{
Su H. Shin \\ Dean R. Lillard \\ Jay Bhattacharya \\ Working Paper 25526 \\ http://www.nber.org/papers/w25526 \\ NATIONAL BUREAU OF ECONOMIC RESEARCH \\ 1050 Massachusetts Avenue \\ Cambridge, MA 02138 \\ February 2019
}

The views expressed herein are those of the authors and do not necessarily reflect the views of the National Bureau of Economic Research.

At least one co-author has disclosed a financial relationship of potential relevance for this research. Further information is available online at http://www.nber.org/papers/w25526.ack

NBER working papers are circulated for discussion and comment purposes. They have not been peer-reviewed or been subject to the review by the NBER Board of Directors that accompanies official NBER publications.

(C) 2019 by Su H. Shin, Dean R. Lillard, and Jay Bhattacharya. All rights reserved. Short sections of text, not to exceed two paragraphs, may be quoted without explicit permission provided that full credit, including $\odot$ notice, is given to the source. 
Understanding the Correlation between Alzheimer's Disease Polygenic Risk, Wealth, and the Composition of Wealth Holdings

Su H. Shin, Dean R. Lillard, and Jay Bhattacharya

NBER Working Paper No. 25526

February 2019

JEL No. D1,D8,I12

\begin{abstract}
We investigate how the genetic risk of developing Alzheimer's Disease (AD) relates to saving behavior. Using nationally representative data from the 1992-2014 Health and Retirement Study (HRS), we find that genetic predisposition for AD correlates with, but is not causally related to older individuals' wealth holdings. People with higher Alzheimer's Disease polygenic risk score (PGS) hold roughly 9 percent more wealth in CDs (hands-off assets) and around 11 percent, 15 percent, and 7 percent less wealth in stocks, IRAs, and other financial assets (hands-on assets) respectively. We explore three hypotheses that could explain these correlations. We hypothesize that people with high risk of $\mathrm{AD}$ choose different portfolios because: (i) they know their polygenic risk of developing Alzheimer's Disease and related dementia, (ii) they have lower cognitive capacity, and (iii) the genome-wide association studies (GWAS) process that generated the Alzheimer's Disease PGS failed to fully account for the aging process. Our extended model results do not support the first two hypotheses. Consistent with the third hypothesis, the interaction between age and the Alzheimer's Disease PGS explains the correlation between genetic traits and asset holdings.
\end{abstract}

$\mathrm{Su}$ H. Shin

University of Alabama

303B Adams Hall

Box 870158

Tuscaloosa, AL 35487

shshin@ches.ua.edu

Dean R. Lillard

Department of Human Sciences

The Ohio State University 1787

Neil Avenue

Columbus, OH 43210

and NBER

lillard.13@osu.edu
Jay Bhattacharya

117 Encina Commons

CHP/PCOR

Stanford University

Stanford, CA 94305-6019

and NBER

jay@stanford.edu 


\section{Introduction}

We explore whether people save differently when they have a greater or smaller polygenic risk of developing Alzheimer's Disease (AD). We take advantage of developments in genetics that have opened up new opportunities for social scientists to better understand and explain how people manage life before ADRD develops. Through large-scale genome-wide association studies (GWAS), researchers have discovered a number of genetic variants (single nucleotide polymorphisms, or SNPs) that exhibit credible and robust associations with the onset of Alzheimer's Disease (Lambert et al. 2013). These genetic markers - present from birth - predict early onset of $\mathrm{AD}$, even before any overt signs of the condition are observable.

The availability of such data has shifted researchers' focus away from the previous method that relied on twin studies. That literature found that genetic traits explain a significant portion of observed variation in active portfolio management (Cesarini et al. 2010), stock market participation and asset allocation (Barnea, Cronqvist, and Siegel 2010), and behavioral biases in investment (Cronqvist and Siegel 2014). The major shortcoming of those studies is that their conclusions may not extend to the non-twin population. With polygenic scores, researchers can identify particular genetic markers associated with various financial decision and explore possible pathways through which such correlations might arise in the general population.

There are good reasons to take advantage of the new polygenic data that are correlated with Alzheimer's Disease and Related Dementias (hereafter ADRD). The Baby Boomers generation is entering into an age range at which people develop ADRD at high rates. Further, a growing number of social scientists have begun to use genetic data to explain social and economic behavior. There is a tendency to assume that genetic risk scores represent random shocks that can be exploited to explain social and economic outcomes. We explore the validity of this assumption.

We study differences in the amount and type of financial assets people hold. ${ }^{1}$ We first show that a person's Alzheimer's Disease polygenic score (PGS) is statistically correlated with (the log of) the value of assets a person holds in six separate asset categories. These include: Certificates of Deposit (CDs), government savings bonds, and treasury bills; publicly traded stocks and stocks held in mutual funds or investment trusts; Individual Retirement Accounts and

\footnotetext{
${ }^{1}$ We find no correlation between Alzheimer's Disease polygenic risk score and net worth, housing assets and nonfinancial assets. Results are available upon request.
} 
Keogh accounts (IRAs); and other financial assets. We characterize assets in these categories according to how actively an investor must manage them. To realize maximum returns available in each category, CD and government-issued securities category require less active management, while stocks and the IRAs require more active management (that is more frequent and complicated portfolio allocation decisions). We label these categories as "hands-off" and "handson” assets respectively. Using data from the 1992-2014 Health and Retirement Study (HRS), we find that people with higher AD polygenic risk hold 9 percent more wealth in "hands-off” assets and around 11 percent, 15 percent, and 7 percent less wealth in "hands-on” assets (see Table 3).

We test three hypotheses that might explain these observed correlations. We hypothesize that persons with a different PGS save/allocate wealth in different ways because...

H1: ...they know their polygenic risk of developing ADRD;

H2: ...they have different levels of cognitive capacity (and their PGS for general cognition is correlated with the Alzheimer's Disease PGS);

H3: ...the GWAS process that generated the Alzheimer's Disease PGS fails to fully account for the aging process.

We motivate $\mathrm{H} 1$ by the idea that foreknowledge of AD risk will alter optimal allocation of investments since a positive AD PGS increases the risk of higher health care and caregiving needs late in life, and reduces expected healthy life years. There is evidence, for instance, that people alter their long run financial plans in response to pertinent new information (Goda, Manchester, and Sojourner 2014; Liebman and Luttmer 2015; Mastrobuoni 2011). Information affects behavior across generations. Among a sample of young Germans, initially unwilling to purchase long-term care insurance for their parents, 30 percent became willing to buy after they were informed of the percentage of old individuals who are currently receiving care; and the means of monthly nursing home costs; length of nursing home stay; and weekly hours of informal caregiving (Zhou-Richter, Browne, and Grundl 2010). Information about at least one of family members’ diagnosis of Alzheimer’s Disease may affect people’s retirement planning decisions. Using sample collected from the University of Utah’s Retirement Planning Survey, researchers find that individuals who had a parental history of Alzheimer's Disease are 86 percent more likely to have consulted with a financial advisor and 40 percent less likely to plan to retire before age 65 (Zick, Smith, and Mayer 2016). Information about individuals’ genetic risk of developing Alzheimer’s Disease may shift demand for long-term care insurance. 
Participants of the Risk Evaluation and Education for Alzheimer's Disease (REVEAL) Study (who were qualified for the program only if they have at least one parent suffering from the disease) were more likely to purchase long-term care insurance when they receive information that they have at least one e4 trait from an APOE test compared to those who discovered to have two e3 traits (Talyor Jr. et al. 2010) and those who did not receive any information (Zick et al. 2005). Thus, if a person knows (or learns) that she faces a higher risk of developing Alzheimer's Disease, she may either hire an agent or allocate more savings to the "hands-off" asset category. To test the first hypothesis we use data on whether a person knows that her parents or her spouse's parents currently have or ever had a memory-related disease.

We motivate $\mathrm{H} 2$ by theory and evidence which suggests that cognitive ability may affect an individuals' decision about how much to earn, save, and allocate savings. Extant literature has documented the relation between cognitive ability and behavioral biases (Benjamin, Brown, and Shaprio 2013; Dohmen et al. 2010; Frederick 2005), and financial decisions and outcomes (Agarwal and Mazumder 2013; Christelis, Jappelli, and Padual 2010; Grinblatt, Keloharju, and Linnainmaa 2011; McArdle, Smith, and Willis 2009). Individuals with better cognitive ability make fewer mistakes when they invest (Agarwal and Mazumder 2013), are more likely to hold any stocks (Christelis et al. 2010; Cole, Paulson, and Shastry 2014; Grinblatt et al. 2011), allocate more assets in stocks (Browning and Finke 2015), and earn greater risk-adjusted returns (Grinblatt, Keloharju, and Linnainmaa 2012).

Evidence also suggests that differences in genetic factors associated with educational attainment explain differences in wealth and financial behavior. Barth, Papageorge and Thom (2017) find that, after controlling for education, labor market earnings, and other factors, retired persons whose educational attainment PGS is one standard deviation higher than the mean education PGS hold 23 percent more wealth than those with the average education PGS. They also show that people with different educational attainment PGS take financial and investment decisions that statistically differ from each other. They find that people with a higher education PGS are more likely to own stocks, know more basics of financial investing, know more about macroeconomics events and stock market returns, and adopt a longer financial planning horizon.

Thus, the AD PGS may simply capture variation in other genetic polygenic scores known to be associated with wealth. GWAS identified thirteen SNPs to be associated with neuropsychiatric phenotypes (Davies et al. 2015). If some of these SNPs also lie along the causal 
pathway that leads to AD or otherwise promotes its ultimate occurrence, then our observed correlation between the AD PGS and portfolio allocation may be due to differences in cognitive ability or other neuropsychiatric phenotypes, rather than due to AD risk itself. To test the second hypothesis we use general cognition PGS and total cognition scores of the respondent and spouse and the interaction of those scores with the AD PGS.

Our third hypothesis explores an implicit assumption - that people do not know their Alzheimer's Disease PGS. This assumption is equivalent to assuming that the Alzheimer's PGS is randomly distributed across people and, more specifically, over people of different ages. We conjecture that, as people advance to old age, they are able to (more precisely) estimate their risk of developing ADRD. When people are younger, there is more variance in the signals of advancing ADRD so some people may choose to ignore the signals. As a person learns that she will grow more forgetful, she will rationally allocate a greater share of her savings into financial instruments that require less active management. ${ }^{2}$ Therefore, as ADRD develops, it will become increasingly apparent that she will develop ADRD. If the GWAS fails to incorporate this agespecific learning process then the AD PGS will not be orthogonal with age. To test this hypothesis, we add to the model the interaction between an individual's AD PGS and his/her age.

Our evidence supports the third hypothesis. Once one accounts for the correlation between age and the AD PGS, the Alzheimer's Disease PGS is uncorrelated with amount of assets a person holds in every category. The results have two implications. First, researchers should think carefully before they assume since an individual's genetic endowment (e.g. polygenic risk score) is outside the control of the individual; i.e. that the PGS can be treated as if were randomly assigned in an analysis of the causal pathway between genotype and a complex outcome that depends on behavior (e.g. asset allocation). Second, when people save, they clearly look forward. Our results are consistent with the idea that when people save in different asset categories, they anticipate that they may grow forgetful or incapable of managing their assets. The results also suggest that consumer welfare might be improved if people took advantage of

\footnotetext{
${ }^{2}$ Our approach is slightly different from that of Korniotis and Kumar (2011), who hypothesized that aging impacts investment behavior through the accumulation of greater investment knowledge from experience but also through cognitive deterioration.
} 
the recently available genetic tests for the genetic factors associated with Alzheimer's Disease, even though no effective medical intervention is available to treat or prevent AD (Galvin 2017).

We next briefly motivate the study of wealth allocation across people with different genetic risks of developing Alzheimer's Disease. In Section III, we describe the data and variables we construct. In section IV, we specify our baseline and extended asset holding models. In the extended models we add variables that are potentially correlated with the AD PGS and we interact them with the AD PGS. We present results in Section V. In section VI we report results from models that explore even more competing explanations. Section VII concludes.

\section{Motivation}

There are good reasons to study whether and how social and economic behavior varies systematically with polygenic risk of various diseases or behaviors in general and with respect to ADRD in particular. Individuals, their families, and Federal and state governments spend quite a bit of money to provide informal and formal care for people with ADRD. These expenditures will grow as the population of people with ADRD grows.

The rightward shift of the demographic bulge implies that the absolute number of older adults with ADRD is increasing. Best available estimates suggest that, in 2017, 5.5 million U.S. residents suffered from ADRD (estimates suggest that 10 percent of Americans age 65 or older suffer from ADRD) (Alzheimer's Association 2017). Because ADRD tends to be underdiagnosed and underreported, researchers have likely underestimated how many Americans suffer or will suffer with ADRD. The Alzheimer's Association (2017) also projects that, by 2025, the number of people 65 and older with ADRD will increase to 7.1 million. This figure represents about a 35 percent increase in the 2017 ADRD population.

The federal government spends relatively more, through Medicare and Medicaid, on people with ADRD versus those without ADRD. In 2016, Medicare spent three times as much to provide health care for ADRD victims than similarly aged beneficiaries without ADRD $(\$ 23,497$ vs \$7,223 respectively) (Alzheimer’s Association 2016). In 2016, average annual Medicaid payments for ADRD victims were 23 times larger than the average payment for those without ADRD (\$8,182 versus \$349 respectively) (Alzheimer’s Association 2016). 
Despite this government spending, ADRD victims, families and friends pay substantial economic, social, emotional and psychological costs. ADRD makes it increasingly difficult for victims to perform normal life activities as it becomes increasingly difficult to follow routines or remember tasks they need to perform in daily activities. The loss of normal routines imposes psychic and emotional costs that may include the trauma involved in leaving one's home to enter a less personalized institutional care facility. Such moves degrade quality of life. Although victims may delay this reduction in quality of life, they do so either by paying directly for a person to provide them with long-term care (LTC) or by getting LTC from a family member.

Long-term care is not cheap. In 2017, the median rates for a semi-private room in a nursing home and for assisted-living facilities were \$7,148 per month and \$3,750 per month (Genworth 2017). ADRD victims may pay less out-of-pocket for long-term care from family members but they and family members still pay both money and non-monetary costs.

Researchers estimate that, in 2016, informal caregivers devoted 18.2 billion hours without pay to care for ADRD victims. Using a median wage as an estimate of the cost of each hour, this time represents an estimated economic value of $\$ 230.1$ billion (Wolff et al. 2016).

Further, recent cohorts of adult children of ADRD victims face higher costs to provide informal care because they have fewer siblings with whom to share the burden and because of competing demands for their time. Higher divorce rates in younger cohorts implies that a given adult child is more likely to be a single parent. Even if a person is married, women now routinely participate in the labor market so both partners have less time available to provide care (and there is less flexibility about when that time falls in the day). People who choose to provide informal care likely suffer greater stress as they juggle the competing demands.

Finally, end-of-life health care costs and the costs of LTC for ADRD victims significantly exceed costs of people with other conditions. Kelley et al. (2015) estimate that total end-of-life and LTC costs in the last 5 years of life were \$341,651 per person for ADRD victims and $\$ 217,820$ per person for non-ADRD victims.

The availability of genetic tests for ADRD has created a dilemma for policy makers and for clinicians providing advice to patients. Genetic tests for ADRD do not help clinicians because there is no effective treatment for ADRD. Therefore, it is irrelevant to a clinician if he/she knows whether a person is likely to develop ADRD. If he/she knows, the recommended 
treatment does not change. On the other hand, genetic tests may improve individual and social welfare because a positive ADRD screen might induce patients to alter their behavior in welfareenhancing ways. For example, on learning one’s ADRD risk, a person may start saving earlier to finance the costs of the care he/she will want later in life. The private savings improves social welfare because it reduces the amount governments need to tax. Finally, some evidence suggests that people adopt more future oriented health behaviors (less smoking, drinking, more exercise) when they have a clearer idea of their ADRD risk. To the extent these behaviors yield higher lifetime utility, private welfare improves.

\section{Data}

We use data from the 1992-2014 waves of the Health and Retirement Study (HRS). The HRS is a biennial longitudinal panel survey that collects a rich set of information about American adults age 50 and older and their spouses. The information includes individuals' demographics, physical and mental health status, disability, financial status such as income, net worth, and housing, insurance, work history and current employment status, retirement status and planning, and family structure (Servais 2004).

\section{Dependent variables}

The HRS collects detailed information on household financial assets. We use data from the RAND HRS wealth file. That file includes household level data on any money or assets held in stocks (publicly held corporations, mutual funds, or investment trusts), cash-equivalent (checking, savings, and money market accounts), retirement accounts (Individual Retirement Account (IRA), Keogh account), certificates of deposit (CDs) (government savings bonds, or treasury bills), bonds (corporate, municipal, government, foreign bonds, or any bond funds), and other financial assets (any other savings or other assets such as jewelry, money owed, a collection for investment purposes, rights in a trust or estate, or an annuity). The data measure the value of each asset. We use the all-items consumer price index to express all values in 2014 dollars.

Polygenic scores for Alzheimer's Disease and Related Dementias and General Cognition

In 2006, 2008, 2010, and 2012 the HRS collected saliva samples from respondents and their spouses in randomly selected households (Ware, Schmitz, and Faul 2018). The HRS 
constructed polygenic risk scores (PGSs) for a large set of phenotypes. To do this, they used a genome-wide association study (GWAS) in which they correlated genetic variants in individuals with a given trait (Faul and Smith 2017). Ware et al. (2018) publish detailed descriptions on how the HRS generated polygenic scores for various traits such as educational attainment, height, Body Mass Index, blood pressure, smoking initiation, subjective wellbeing, depressive symptoms, etc. The HRS provides scores including all available SNPs that overlap between the GWAS and the HRS genetic data. The PGSs consist of the weighted sum of the genotype (the number of reference alleles for individuals at each SNP - zero, one, or two). The HRS chose weights of the odds ratio or beta estimates corresponding to the phenotype of interest obtained from GWAS.

Our primary independent variable is the PGS for Alzheimer's Disease and Related Dementias. The HRS's most recent version of the data includes two polygenic scores for Alzheimer's Disease; one version includes the two SNP variants known to be associated with apolipoprotein E (APOE) status (rs7412, and rs429358); the other version of the AD PGS omits those two variants. Both scores include 19 single nucleotide polymorphisms (SNPs) associated with Alzheimer's Disease. Because the two excluded SNPs account for very little of the overall correlation with AD, the two PGSs are almost perfectly correlated (r=0.99992) (Ware et al. 2018). In our main analyses, figure and tables, we report the estimates from models using Alzheimer's Disease PGS that includes the ApoE status variants. We report results from models that use the PGS without the ApoE status variants in appendix Tables A12-A18. The results from the two measures are virtually identical.

Figure 1 plots the kernel density estimates for the Alzheimer's Disease PGS that includes the ApoE status variants. The distribution of the Alzheimer's Disease PGS variables is approximately normal. As is typical, we normalize the Alzheimer's Disease PGS variable, so that the coefficient on the PGS in multivariate regressions represents the percentage change in the asset of interest in response to a one standard deviation change in the Alzheimer's Disease PGS.

The HRS created the PGS for general cognition based on thirteen SNPs in three separate regions associated with general cognitive function phenotypes (Davies et al. 2015). The HRS used the weights provided by the Cohorts for Heart and Aging Research in Genomic Epidemiology (CHARGE) consortium and adjusted for age, sex, population stratification, and 
cohort-specific covariates such as familiar relationship (Ware et al. 2018). The PGS for general cognition is also standardized with mean of zero and standard deviation of one.

To explore mechanisms, we draw respondent's and his/her spouse's parents’ history of memory disease/problems, scores from HRS administered cognition tests, self-reported memory, tolerance for risk, and financial planning horizon. We estimate models that include these variables and sometimes their interaction with the AD PGS. We briefly describe them next.

Parental history of memory problems/diagnosis (MRD): The 1998-2008 HRS surveys asked respondents about their parent's history of memory problems. HRS only asked the question of respondents with at least one living parent. HRS asked those respondents whether a doctor has ever told their mother (father) that she (he) has a memory-related disease. The 20102014 surveys ask respondents if a doctor has ever diagnosed the respondent's mother and father with Alzheimer's or Dementia. We ignore the wording differences and use these data to create a time-invariant variable that equals one if a respondent had at least one parent who has ever had a memory-related problem/disease. We create the same dummy variable for his/her spouse. Note that the respondent's parent had to be alive to answer the question. We use all of the available data so we create this indicator for respondents whose parents subsequently died. Respondents reported that approximately 11 percent of their mothers and 4 percent of their fathers suffered a memory-related disease/problem.

In Table A10 of the Appendix we investigate whether the Alzheimer's disease PGS vary systematically across the sample of respondents (spouses) who had a parent with a history of memory-related disease. We find that that parental history of memory-related disease is not statistically significantly related to the degree of genetic risk of developing Alzheimer's Disease.

Cognition scores: The total cognition score measures memory and knowledge, language, and orientation skills (Fisher et al. 2017). To construct cognition scores the HRS administers two word-recall exercises with each respondent and his spouse and a test of a person's mental status. The word recall exercises are just what the name implies - respondents read a list of words and then must recall as many as they can - immediately and after some delay. For the mental status test respondents must add up a series of 7s, count backwards from 20, and identify who is the President and/or Vice-President of the United States. Ofstedal, Fisher, and Herzog (2005) describe these measures in more detail. 
We use the RAND HRS version of the cognition scores. RAND imputed cognition scores for people who failed to take the tests. They did not impute values for people who did not participate at all in a given survey wave or for people whose data were reported by a proxy respondent. To impute the scores, RAND uses a multivariate regression model that includes time-invariant baseline demographic characteristics, wave-specific demographics, other timevarying factors associated with cognitive functioning, and past and current wave cognition scores. Fisher et al. (2017) describe more details of the imputation procedure. In our model of savings, we standardized the total cognition score variable, setting its mean to zero and standard deviation to one.

Self-rated memory: The HRS asks respondents, "How would you rate your memory at the present time? Would you say it excellent, very good, good, fair, or poor?” The responses range from one (excellent) to five (poor). We reverse the scores, so that higher scores indicate better perception of memory. We standardize the variable so we can interpret the corresponding coefficient as the effect of a one-standard deviation increase in self-assessed memory.

In Table A11 of the Appendix we examine whether self-rated memory varies systematically with the two Alzheimer's disease PGS. In general, we find that that the AD PGS is statistically significantly and negatively related to the level of self-assessed memory capacity.

Risk tolerance: To measure a respondent's risk aversion, the HRS asks respondents a set of income gamble questions. They ask him/her to choose between pairs of jobs where one guarantee current family income and the other offers a chance to increase income but also carries the risk of loss of income. The second job would double income with even chances (50-50) or cut it by X. The income loss scenarios provided in the HRS are: "10 percent, 20 percent, a third, half, and 75 percent.” HRS asked the questions in only five survey waves (1992 and 1998-2006). We create a dummy variable of whether a respondent is risk averse by coding the variable as one if he/she choose to take a job that guarantees current income over the second job that may double income or cut it by 10 percent and as zero otherwise. Approximately 61 percent and 62 percent of the respondents and spouses exhibit risk averse preferences (Table 1). When risk aversion data were missing but available in the previous wave, we use those data.

Planning horizon: Another possible mechanism that might explain the correlation between the Alzheimer's Disease PGS and savings is the planning horizon. If a person with high polygenic 
risk of developing Alzheimer's Disease has a systematically shorter or longer time horizon, it may affect his/her portfolio allocation. In order to measure a person's financial planning horizon, the HRS asks the question, “In planning your family's saving and spending, which time period is more important to you?” The percent of the respondents and spouses in the sample reporting in each category were, respectively: "next few months (10.7 \& 11.3)," "next year (12.0 \& 12.1)," “next few years (29.6 \& 29.5),” “next 5-10 years (35.9 \& 34.9),” and “longer than 10 years” (11.9 \& 12.3).

\section{Sample selection}

Following the literature, we restrict our sample to HRS respondents who are from European ancestry because the sample researchers used to derive the SNP weights was almost exclusively of European ancestry. It is well-known that when one generates PGS for individuals from other ancestry groups, the PGS predict poorly (sometimes absurdly) (Martin et al. 2017; Ware et al. 2018). We further restrict our sample to couples with non-missing values on genetic, age, education, health status, medical conditions, difficulties with performing activities of daily livings (ADLs) and instrumental activities of daily livings (IADLs), self-rated memory, employment status, and number of years of work of respondents and spouses, number of living children, household income, and financial assets. Our analytic sample includes 8,787 individuals (45,245 person-year observations).

Table 1 presents summary statistics on the sample’s basic characteristics. Because we include both respondents and spouses in our analyses, summary statistics on household characteristics of respondent and spouses are almost identical. The majority of our sample earned at least a high school degree (89\%), had at least good health (83\%), and was either retired or not working (69\%). The mean age of our average sample member was 66. The average respondent worked for 36 years. The average total cognition scores of the respondents and spouses are 23.36 (S.D.= 3.60) and 23.00 (S.D.= 4.06, respectively.

Table 2 shows the mean, $10^{\text {th }}, 25^{\text {th }}, 50^{\text {th }}, 75^{\text {th }}$, and $90^{\text {th }}$ percentiles of total financial assets and each financial instruments. The mean value (2014\$) of assets held in financial assets, stocks, cash equivalent, IRAs, CDs, bonds, other financial assets is $\$ 350,390, \$ 119,446, \$ 42,734$, $\$ 120,755$, \$25,115, \$19,278, and \$23,063, respectively. Unsurprisingly, the distribution of each type of assets is highly skewed. The median household holds much less of each asset. In these 
same asset categories, the median household holds $\$ 118,565$, $\$ 0, \$ 12,530, \$ 16,496, \$ 0$, $\$ 0$, and $\$ 0$, respectively. For some financial instruments, ownership is less common (e.g., only 11 percent of individuals own bonds). A majority of our sample holds at least one type of financial asset (96.79\%) and cash-equivalents (93.36\%).

\section{Empirical model}

We adopt a simple method. We first specify a model of each household's (log) assets of several different types. These include all financial assets, stocks, cash, IRAs, CDs, bonds, and other financial assets. Each model includes the respondent's and his/her spouse's Alzheimer's Disease PGS and a set of standard control variables as follows:

$$
\log \left(\text { fin }_{i t}\right)=\alpha_{0}+\alpha_{1} A D P G S_{i}+X_{i t}+t_{t}+\varepsilon_{i t}
$$

$A D P G S_{i}$ denotes Alzheimer's Disease PGS with ApoE status variants. $X_{i t}$ includes: the first ten principal components of the genetic data, ${ }^{3}$ age, age-squared, education, self-reported health status, number of medical conditions diagnosed by a doctor, number of difficulties with performing ADLs and IALDs, self-rated memory, employment status, birth cohort, and total number of years worked of both respondents and spouses, household income, number of living children, and year dummies. We control for spouses' characteristics because the HRS collects detailed information about asset holdings at the household-level rather than individual-level. We use random-effect regression models for all specifications, and cluster standard errors by households. As robustness tests, we also estimate the baseline models (1) using random-effect tobit models, and the significance of the main variables do not change. We report the results in Table A12A and A12B in Appendix. Unless otherwise indicated, we always include the same set of control variables.

We then extend the models to explore possible ways the correlations arise. These include the potential that the AD PGS captures variation from omitted variables. In separate models we add the reference person and his spouse's: 1) parents memory problem indicator (Table 4); 2) general cognition PGS and total cognition scores (Table 5); 3) AD PGS interacted with age

\footnotetext{
${ }^{3}$ Researchers recommended controlling for the ten principal components of the genetic data to account for a potential association between genetic factors and ancestry groups and population stratification in GWAS (Price et al., 2006; Benjamin et al., 2012; Barth et al., 2017).
} 
(Table 6); 4) self-rated memory (Table 7); 5) risk aversion (Table 8); and 6) financial planning horizon (Table 9). Generically these models take the form:

$$
\log \left(\text { fin }_{i t}\right)=\alpha_{0}+\alpha_{1} A D P G S_{i}+\alpha_{2} Z_{i}+\alpha_{3} A D P G S_{i} * Z_{i}+X_{i t}+t_{t}+\varepsilon_{i t}
$$

where $Z_{i}$ is the potentially omitted variable. We add the interaction between $Z_{i}$ and the respondent's (spouse's) AD PGS for all but the risk aversion and financial planning horizon variables. We do not interact those variables with the AD PGS.

We include risk aversion in our extended model as one of the potentially omitted variables because some researchers argue that individuals differ in their savings and savings behavior because they differ in their person's willingness take financial risk (Cohn et al. 1975; Friend and Blume 1975; Guiso, Haliassos, and Bertaut 2002; Morin and Suarez 1983; Pålsson 1996; Palme, Sundén, and Söderlind 2007). Researchers have found evidence that cognitive abilities partly explain variations in a person's willingness to take risks (Bonsang and Dohmen 2015; Dohmen et al. 2010), and thus her portfolio choices.

\section{Results}

In our basic specification, if it is true that the genetic endowment is exogenous to economic and financial outcomes, a respondent's and her spouse's Alzheimer's Disease PGS should not be related to the amount and type of assets she holds. In contrast, Table 3 suggest that Alzheimer's Disease PGS is significantly associated with asset holdings in total financial assets, stocks, IRA, other financial assets, and CDs. Respondents and spouses whose Alzheimer's Disease PGS is one standard deviation above the mean hold approximately 5, 11, 15 and 7 percent less in total financial assets, stocks, IRAs, and other financial assets, respectively. If she has an Alzheimer's Disease PGS that is one standard deviation above the mean then she holds roughly 9 percent more wealth in CDs.

Table 4 presents coefficient estimates from the extended model that controls for a parental history of memory problems and the interaction of that indicator with the AD PGS. Parental history of memory problems explains variation in asset holding but not the association between asset holding and the AD PGS. People save more in financial assets, cash-equivalent, IRAs, and other financial assets when they have parents who have been diagnosed with memory problems. In particular, if a person has a parental history of memory problems, she saves 
statistically significantly more in total financial assets by 19 percent, in cash-equivalent by 19 percent, and other financial assets by 39 percent while his/her spouse's parental history of memory-related disease is associated with increases in total financial assets by 30 percent, cashequivalent by 24 percent, IRAs by 29 percent, and other financial assets by 36 percent. However, our basic result remains even after allowing the association between asset holding and the AD PGS to vary across people with/without a parental history of memory-related disease. A person with higher genetic risk of Alzheimer's Disease saves less in stocks (13 percent) and IRAs (17 percent) and saves more in CDs (9 percent); these associations remain statistically significant. Thus, the first hypothesis does not fully explain the association between savings and the Alzheimer's Disease PGS.

Table 5 presents coefficient estimates from the extended model that controls for the respondent and spouses' cognition PGS, the HRS total cognition score, and the interaction of both variables with the AD PGS. Across all categories of assets, the PGS for general cognition is uncorrelated with savings and there is no statistically significant different in the general cognition PGS across people with higher/lower AD PGS.

While Table 5 results show that respondents and spouses with higher total cognition scores hold more of almost all asset types, the interaction of the cognition and Alzheimer's polygenic sores does not explain our basic finding. The first result comports with previously reported findings that cognitive ability is correlated with financial decisions, especially stock market participation (Christelis et al. 2010; Grinblatt et al. 2011). Her spouse’s cognition score is positively correlated with asset holdings in most of the financial instruments except for CDs. Controlling for the interaction between the total cognition score and the Alzheimer's Disease PGS, a person with higher genetic risk of developing Alzheimer's Disease still saves 7, 16, and 8 percent less in financial assets, IRAs, and other financial assets respectively. A person with a higher AD PGS holds 13 percent more in CDs. The effect size of Alzheimer's Disease PGS on savings in these financial instruments is slightly greater than that presented in Table 3. Thus, the second hypothesis does not explain the correlation between the Alzheimer's Disease PGS and saving decisions.

Table 6 reports results from the extended model that interacts the Alzheimer's Disease PGS with age and age-squared (divided by 1000). We do this to test the hypothesis that the AD 
PGS of a given individual varies systematically with his/her age. We also report the chi-squared statistics on the test of the joint significance of the coefficients on every variable involving the respondent/spouse AD PGS.

The AD PGS interaction terms capture differences in the AD PGS-asset holding association across people of different ages. Holding those differences constant, the coefficient on the AD PGS measures the variation in holdings of each asset type across people with different AD PGS.

Table 6 presents three main results. First, there is evidence that the AD PGS-asset holding correlation differs with age for stocks. Second, holding constant age-related differences in the AD PGS-asset holdings correlation, people with higher AD PGS hold substantially fewer assets in stocks. Third, in the other asset categories, accounting the age-related differences in the AD PGS-asset holding correlation explains the basic finding. After controlling for the interaction, people with different Alzheimer's Disease PGS do not save more or less overall or in IRAs, CDs, and other financial assets. We find supporting evidence for the third hypothesis: if we account for the interplay between age and Alzheimer's Disease PGS, the Alzheimer's Disease PGS can be considered to be an exogenous assignment.

\section{Extended model results}

In Table 7, Table 8 and Table 9 we considered additional variables omitted from the basic model that might account for the baseline findings we report in Table 3.

Table 7 reports results when we add a measure of a person's self-reported memory problems and interact it with the AD PGS. Results are almost identical to results in our Table 3 baseline models. Even after controlling for the interaction term, a one-standard deviation increase in a person's Alzheimer's PGS is associated with decreases in asset holdings in total financial assets, stocks, IRAs, and other financial assets and with an increase in savings in CDs. Therefore, individuals' perception about their memory does not fully account for the correlation between the Alzheimer's Disease PGS and savings. This seems to suggest that individuals' learning process through aging is not fully reflected in their self-rated perception of memory, but it is rather a more complex process. 
Table 8 presents results from the model that adds a measure of risk aversion. The results suggest that differences in an individual's risk aversion may explain some of the correlation between the Alzheimer's Disease PGS and savings in a particular type of assets. The effect of the Alzheimer's Disease PGS on the amount savings in total financial assets, stocks, and CDs is no longer statistically significant and the size of the effect decreases compared to the baseline model presented in Table 3. However, the effect of a person's Alzheimer's Disease PGS on the amount saved in IRAs and other financial assets remains statistically different from zero $(\mathrm{p}<0.05)$. Specifically, the person's Alzheimer's Disease PGS is associated with decreases in asset holdings in IRAs and other financial assets by 13 percent and 8 percent, respectively. The result indicates that a person's willingness to take risk may account for the correlation between the Alzheimer's Disease PGS and savings in total financial assets, stocks, and CDs but not savings in IRAs and other financial assets, and thus the third hypothesis (the learning by aging process) might be a better explanation for the association.

Table 9 reports results from the models that include the variables that flag a respondent's planning horizon. Results show that people with longer planning horizons allocate more wealth in total financial assets, stocks, cash-equivalent, IRAs, CDs, and other financial assets. This result is similar to results presented in Barth et al. (2017). We find a similar pattern for the relation between her spouse's time horizon and household savings. After adding these variables, the correlation between the Alzheimer's Disease PGS and savings in other financial assets is no longer statistically significant. The coefficient on the respondent's Alzheimer's Disease PGS remains statistically significant in the model of savings in total financial assets, stocks, IRAs and CDs. Thus, we conclude that the planning horizon does not fully account for the correlation between the Alzheimer's Disease PGS and savings.

\section{Conclusion}

We start with a basic result that suggests that one observes different savings behavior between people with lower and higher genetic risk of developing Alzheimer's Disease. In our basic models, we find that people with higher risk of developing Alzheimer's Disease save more in assets that require less active management and less in assets that need to be managed more. This pattern is not consistent with the assumption that people do not know their genetic risk of developing ADRD. This pattern seems consistent with several possible mechanisms that we 
explore. We explored whether people might know their potential for developing Alzheimer's disease from their family histories; whether they were cognitively limited; and whether they might begin to realize with more precision their risk of developing ADRD as they age.

Our results suggest that the latter explanation accounts for the observed correlation between savings (of a given type) and the genetic risk of developing Alzheimer's Disease. We find that once one controls for the correlation between age and the Alzheimer's PGS, the direct association between savings of a particular type and the Alzheimer’s PGS disappears.

This finding suggests that, as people age, those with higher Alzheimer's Disease PGS alter their savings type and amounts. Such changes in behavior may simply reflect a person's recognition of accumulating forgetfulness or it may reflect a more complicated process that involves adult children more actively intervening. The results suggest that people might adjust their savings behavior if doctors would use genetic tests to inform them whether they face a higher risk of developing ADRD later in life. A second and important implication of our results is that genomics researchers should explore whether or not it makes sense to assume people do not know their genetic risk of any given behavior.

\section{References}

Agarwal, S., and B. Mazumder. 2013. Cognitive abilities and household financial decision making. American Economic Journal: Applied Economics 5(1): 193-207.

Alzhiemer’s Association. 2016. Medicare current beneficiary survey report. Unpublished Report. Alzhiemer's Association. 2017. 2017 Alzheimer's Disease facts and figures. Alzheimer's \& Dementia 13(4): 325-373.

Barnea, A., H. Cronqvist, and S. Siegel. 2010. Nature or nurture: What determines investment behavior? Journal of Financial Economics 98(3): 583-604.

Barth, D., N. W., Papageorge, and K. Thom. 2017. Genetic ability, wealth, and financial decision-making. IZA Discussion Papers 10567, Forschungsinstitut zur Zukunft der Arbeit. Available at https://www.iza.org/publications/dp/10567/genetic-ability-wealth-and-financialdecision-making

Benjamin, D. J., S. A. Brown, and J. M. Shapiro. 2013. Who is 'behavioral'? Cognitive ability and anomalous preferences. Journal of the European Economic Association 11(6): 1231-1255.

Benjamin, D. J., D. Cesarini, C. F. Chabris, E. L. Glaeser, D. I. Laibson, V. Guðnason, T. B. Harris, L. J. Launer, S. Purcell, A. V. Smith, et al. 2012. The promises and pitfalls of genoeconomics. Annual Review of Economics 4: 627-662. 
Browning, C., and M. Finke. 2015. Cognitive ability and the stock reallocations of retirees during the Great Recession. The Journal of Consumer Affairs Summer: 356-375.

Cesarini, D., M. Johannesson, P. Lichtenstein, Ö. Sandewall, and B. Wallace. 2010. Genetic variation in financial decision-making. Journal of Finance 65(5): 1725-1754.

Christelis, D., T. Jappelli, and M. Padula. 2010. Cognitive abilities and portfolio choice. European Economic Review 54: 18-38.

Cole, S., A. Paulson, and G. K. Shastry. 2014. Smart money? The effect of education on financial outcomes. The Review of Financial Studies 27(7): 2022-2051.

Cohn, R. A., W. G. Lewellen, R. C. Lease, and G. G. Schlarbaum. 1975. Individual investor risk aversion and investment portfolio composition. Journal of Finance 30: 605-620.

Cronqvist, H., and S. Siegel. 2014. The Genetics of Investment Biases. Journal of Financial Economics 113(2): 215-234.

Davies, G., N. Armstrong, J. C. Bis, J. Bressler, V. Chouraki, S. Giddaluru, ..., \& S. J. Van Der Lee. 2015. Genetic contributions to variation in general cognitive function: A meta-analysis of Genome-Wide Association Studies in the CHARGE consortium $(\mathrm{N}=53,949)$. Molecular Psychiatry 20(2): 183-192.

Dohmen, T., A. Falk, D. Huffman, and U. Sunde. 2010. Are risk aversion and impatience related to cognitive ability? American Economic Review 100(3): 1238-1260.

Faul, J., and J. A. Smith. 2017. Health and Retirement Study: Genetic data consortia collaboration. Institute for Social Research, University of Michigan, Ann Arbor, MI. Available at https://hrs.isr.umich.edu/sites/default/files/biblio/Genetic\%20Data\%20Consortia.pdf.

Fisher, G. G., H. Hassan, J. D. Faul, and W. L. Rodgers. 2017. Health and Retirement Study imputation of cognitive functioning measures: 1992-2014. Survey Research Center, University of Michigan, Ann Arbor, MI.

Frederick, S. 2005. Cognitive reflection and decision making. Journal of Economic Perspectives 19(4): 25-42.

Friend, I., and M. E. Blume. 1975. The demand for risky assets. American Economic Review 65: 900-922.

Galvin J. E. 2017. Prevention of Alzheimer's Disease: Lessons learned and applied. Journal of the American Geriatrics Society 65(1): 2128-2133.

Genworth. 2017. Genworth 2017 cost of care survey. Available at https://www.genworth.com/aging-and-you/finances/cost-of-care.html

Goda, G. S., C. F. Manchester, and A. J. Sojourner. 2014. What will my account really be worth? Experimental evidence on how retirement income projections affect saving. Journal of Public Economics 119: 80-92. 
Grinblatt, M., M. Keloharju, and J. Linnainmaa. 2011. IQ and stock market participation. Journal of Finance 66(6): 2119-2164.

Grinblatt, M., M. Keloharju, and J. Linnainmaa. 2012. IQ, trading behavior, and performance. Journal of Financial Economics 104: 339-362.

Guiso, L., M. Haliassos, and T. Jappelli. 2002. Household Portfolio. MIT Press, Cambridge, MA.

Kelley, A. S., K. McGarry, R. Gorges, and J. S. Skinner. 2015. The burden of health care costs for patients with dementia in the last 5 years of life. Annals of Internal Medicine 163:729-736.

Korniotis, G. M., and A. Kumar. 2011. Do Older Investors Make Better Investment Decisions? The Review of Economics and Statistics 93(1): 244-265.

Lambert, J-C., C. A. Ibrahim-Verbaas, D. Haorld, et al. 2013. Meta-analysis of 74,046 individuals identifies 11 new susceptibility loci for Alzheimer's Disease. Nature Genetics 45: 1452-1458.

Liebman, J. B., and E. F. P. Luttmer, 2015. Would people behave differently if they better understood Social Security? Evidence from a field experiment. American Economic Journal: Economic Policy 7(1): 275-299.

Martin, A. R., C. R. Gignoux, R. K. Walters, G. L. Wojcik, B. M. Neale, S. Gravel, M. J. Daly, C. D. Bustamante, and E. E. Kenny. 2017. Human demographic history impacts genetic risk prediction across diverse populations. The American Journal of Human Genetics 100(4), 635649.

Mastrobuoni, G. 2011. The role of information for retirement behavior: Evidence based on the stepwise introduction of the Social Security Statement. Journal of Public Economics 92: 913925.

McArdle, J. J., J. P. Smith, and R. Willis. 2009. Cognition and economic outcomes in the Health and Retirement Survey. NBER Working Paper 15266, National Bureau of Economic Research, Cambridge, MA.

Morin, R. A., and A. F. Suarez. 1983. Risk aversion revisited. Journal of Finance 38: 12011216.

Ofstedal, M. B., G. G. Fisher, and A. R. Herzong. 2005. Documentation of cognitive functioning measures in the Health and Retirement Study. HRS Documentation Report DR-006. Survey Research Center, University of Michigan, Ann Arbor, MI.

Palme, M., A. Sundén, and P. Söderlind. 2007. Investment choice in the Swedish premium pension plan. Journal of the European Economic Association 5: 636-646.

Pålsson, A.-M. 1996. Does the degree of relative risk aversion vary with household characteristics? Journal of Economic Psychology 17: 771-787. 
Price, A. L., N. J. Patterson, R. M. Plenge, M. E. Weinblatt, N. A. Shadick, and D. Reich. 2006. Principal components analysis corrects for stratification in Genome-Wide Association Studies. Nature Genetics 38 (8): 904-909.

Servais, M. A. 2004. Overview of HRS public data files for cross-sectional and longitudinal analysis. Institute for Social Research, University of Michigan, Ann Arbor, MI.

Taylor, Jr., D. H., R. M. Cook-Deegan, S. Hiraki, J. S. Roberts, D. G. Blazer, and R. C. Green. 2010. Genetic testing for Alzheimer's and long-term care insurance. Health Affairs 29(1): 102108.

Ware, E., L. L. Schmitz, and J. D. Faul. 2018. HRS documentation report. HRS polygenic scores 2006-2012 genetic data. Institute for Social Research, University of Michigan, Ann Arbor, MI.

Ware, E., L. L. Schmitz, J. D. Faul, A. M. Gard, J. A. Smith, C. M. Mitchell, D. R. Weir, and S. L. R. Kardia. 2017. Heterogeneity in polygenic scores for common human traits. BiorXiv. Available at https://doi.org/10.1101/106062

Wolff, J. L., B. C. Spillman, V. A. Freedman, and J. D. Kasper. 2016. A national profile of family and unpaid caregivers who assist older adults with health care activities. JAMA Internal Medicine 176(3): 372-379.

Zhou-Richter, T., M. J. Browne, and H. Grundl. 2010. Don’t they care? Or, are they just unaware? Risk perception and the demand for long-term care insurance. The Journal of Risk and Insurance 77(4): 715-747.

Zick, C. D., C. J. Mathews, J. S. Roberts, R. Cook-Deegan, R. J. Pokorski, and R. C. Green. 2005. Genetic testing for Alzheimer's Disease and its impact on insurance purchasing behavior. Health Affairs 24(2): 483-490.

Zick, C. D., K. R. Smith, and R. N. Mayer. 2016. Planning ahead or living a day at a time? A family history of AD and retirement planning. American Journal of Alzheimer's Disease \& Other Dementias 31(6): 516-523. 


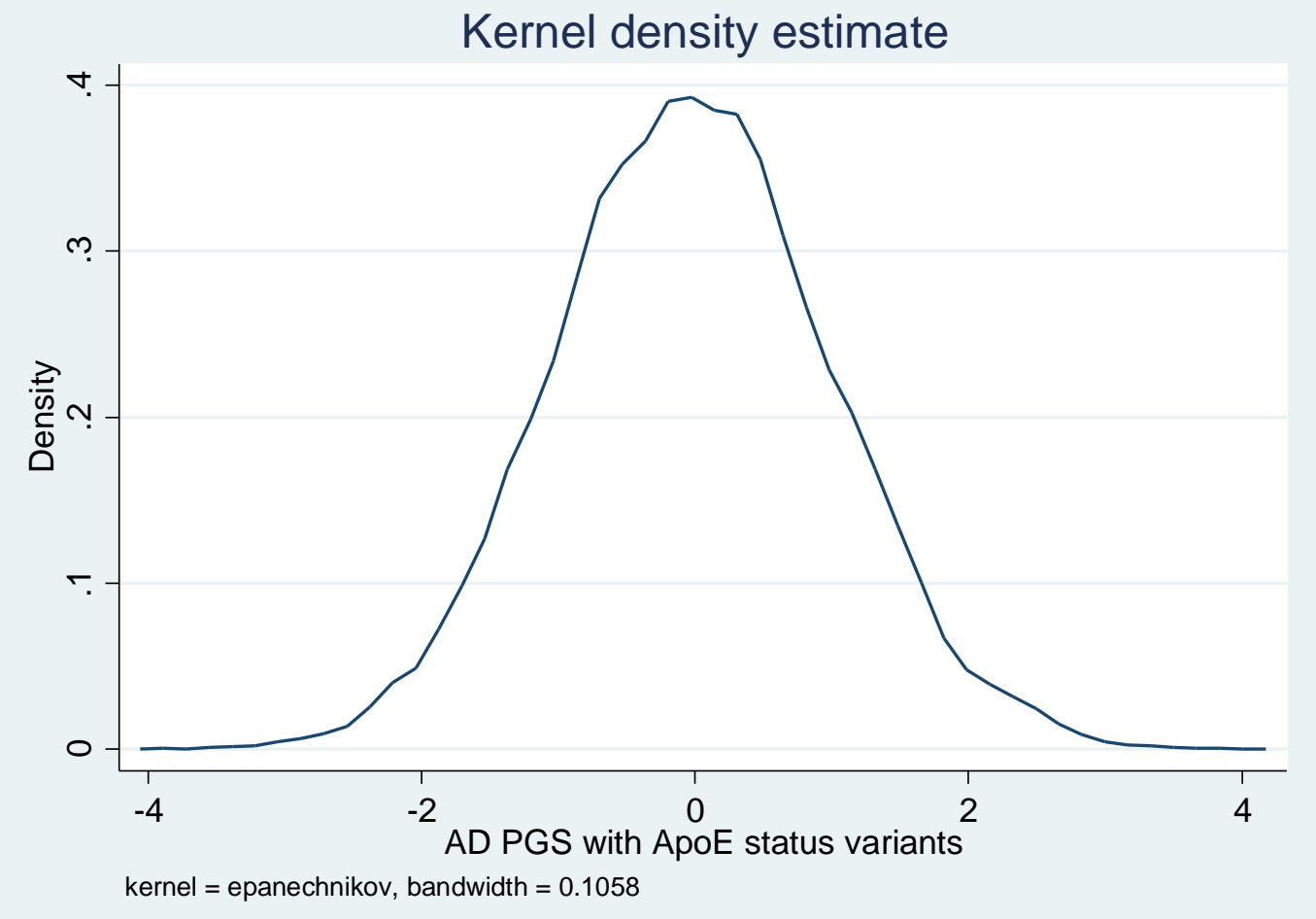

Figure 1. Distribution of Alzheimer's Disease PGS. 


\begin{tabular}{|c|c|c|}
\hline Variable & Respondent & Spouse \\
\hline Age & $\begin{array}{l}66.44 \\
(8.42)\end{array}$ & $\begin{array}{l}66.23 \\
(9.36)\end{array}$ \\
\hline \multicolumn{3}{|l|}{ Educational attainment } \\
\hline$\overline{\text { High school dropouts }}$ & 0.12 & 0.13 \\
\hline High school graduate & 0.37 & 0.36 \\
\hline Some college & 0.25 & 0.25 \\
\hline College or more (BA) & 0.27 & 0.27 \\
\hline \multicolumn{3}{|l|}{ Health status } \\
\hline Poor & 0.04 & 0.05 \\
\hline Fair & 0.13 & 0.13 \\
\hline Good & 0.31 & 0.31 \\
\hline Very good & 0.37 & 0.36 \\
\hline Excellent & 0.15 & 0.14 \\
\hline \multirow[t]{2}{*}{ \# of medical conditions } & 0.20 & 0.21 \\
\hline & $(0.27)$ & $(0.29)$ \\
\hline \# of ADLs perform with difficulty & $\begin{array}{c}0.17 \\
(0.54)\end{array}$ & $\begin{array}{c}0.20 \\
(0.64)\end{array}$ \\
\hline \# of IADLs perform with difficulty & $\begin{array}{c}0.18 \\
(0.45)\end{array}$ & $\begin{array}{c}0.21 \\
(0.57)\end{array}$ \\
\hline \multicolumn{3}{|l|}{ Employment status } \\
\hline Employed & 0.31 & 0.31 \\
\hline Retired & 0.59 & 0.60 \\
\hline Not working & 0.10 & 0.10 \\
\hline Years worked & $\begin{array}{c}35.58 \\
(14.03)\end{array}$ & $\begin{array}{c}35.38 \\
(14.28)\end{array}$ \\
\hline Self-rated memory & $\begin{array}{c}3.08 \\
(0.75)\end{array}$ & $\begin{array}{c}3.08 \\
(0.76)\end{array}$ \\
\hline Total cognition score & $\begin{array}{l}23.36 \\
(3.60)\end{array}$ & $\begin{array}{l}23.00 \\
(4.06)\end{array}$ \\
\hline \multicolumn{3}{|l|}{ Risk Aversion } \\
\hline \multicolumn{3}{|l|}{ Planning horizon } \\
\hline Next few months & 10.71 & 11.28 \\
\hline Next year & 11.95 & 12.06 \\
\hline Next few years & 29.58 & 29.46 \\
\hline Next 5-10 years & 35.88 & 34.94 \\
\hline Longer than 10 years & 11.88 & 12.26 \\
\hline \multicolumn{3}{|l|}{ Birth cohort (years) } \\
\hline Not in any cohort & 0.00 & 0.04 \\
\hline$<1924$ & 0.07 & 0.08 \\
\hline 1924-1930 & 0.14 & 0.15 \\
\hline
\end{tabular}




$\begin{array}{ccc}\text { 1931-1941 } & 0.36 & 0.35 \\ 1942-1947 & 0.16 & 0.15 \\ 1948-1953 & 0.15 & 0.14 \\ 1954-1959 & 0.12 & 0.10 \\ \text { \# of living children } & 3.26 & \\ & (1.92) & \\ \text { Household income (2014 \$) } & 97,975 & \end{array}$

$(111,567)$

Notes. Standard deviations appear in parentheses under the mean value of the continuous variables. Summary statistics are unweighted. $(\mathrm{N}=8,787)$; $\mathrm{N}$ (household-year)=45,245.

Table 2. Mean Asset Holdings - by type and percentile of type distribution

\begin{tabular}{lcccccccc}
\hline & & & & & & $\%$ \\
& $10 \%$ & $25 \%$ & $50 \%$ & $75 \%$ & $90 \%$ & Mean & S.D. & ownership \\
\hline \hline Financial assets & 2,171 & 21,993 & 118,565 & 382,168 & 869,874 & 350,390 & 695,442 & 96.79 \\
Stocks & 0 & 0 & 0 & 61,860 & 301,598 & 119,446 & 415,614 & 43.28 \\
Cash & & & & & & & & \\
Equivalent & 345 & 3,299 & 12,530 & 39,178 & 103,100 & 42,734 & 82,184 & 93.36 \\
IRAs & 0 & 0 & 16,496 & 121,658 & 336,895 & 120,755 & 239,048 & 58.46 \\
CDs & 0 & 0 & 0 & 5,285 & 59,698 & 25,115 & 76,661 & 30.56 \\
Bonds & 0 & 0 & 0 & 0 & 5,155 & 19,278 & 148,408 & 11.01 \\
Other & 0 & 0 & 0 & 0 & 34,366 & 23,063 & 101,506 & 23.25 \\
\hline
\end{tabular}

Note. Figures in real 2014 dollars. Summary statistics are unweighted. N(person) $=8,787$;

$\mathrm{N}$ (household-year) $=45,245$. Other assets include any other savings or assets such as jewelry, money owed to you by others, a valuable collection for investment purposes, an annuity, and rights in a trust or estate. 
Table 3. Log of assets and Alzheimer's Disease Polygenic Score (AD PGS), by asset type

\begin{tabular}{lccccccc}
\hline AD PGS & Financial assets & Stocks & Cash & IRA & CD & Bonds & Other \\
\hline \hline Own AD PGS & $-0.0547^{*}$ & $-0.1141^{*}$ & -0.0106 & $-0.1519^{* *}$ & $0.0912^{*}$ & -0.0293 & $-0.0695^{*}$ \\
& $(0.0242)$ & $(0.0450)$ & $(0.0207)$ & $(0.0493)$ & $(0.0376)$ & $(0.0259)$ & $(0.0303)$ \\
Spouse AD PGS & -0.0480 & -0.0613 & -0.0010 & $-0.1575^{* *}$ & 0.0475 & -0.0126 & -0.0607 \\
& $(0.0264)$ & $(0.0519)$ & $(0.0227)$ & $(0.0571)$ & $(0.0429)$ & $(0.0292)$ & $(0.0348)$ \\
Constant & 2.6083 & $-7.0741 *$ & 1.6408 & $-11.2894^{* * *}$ & $-5.7894^{*}$ & $-8.7918^{* * *}$ & $-4.4502^{*}$ \\
& $(1.3445)$ & $(2.8143)$ & $(1.4910)$ & $(2.7801)$ & $(2.5663)$ & $(1.7809)$ & $(2.2366)$ \\
\hline \hline $\mathrm{R}^{2}$ & 0.2634 & 0.1617 & 0.1411 & 0.1470 & 0.0679 & 0.0805 & 0.0745 \\
\hline
\end{tabular}

Notes: N(household-year)=45,245. N(persons)=8,787. Random effects model coefficients. Robust standard errors in parentheses. $*$, $* *$, *** denote coefficients that differ from zero with $\mathrm{p}<0.05, \mathrm{p}<0.01$, and $\mathrm{p}<0.001$ respectively. We control for the first ten principal components of the genetic data, age, age-squared, education, self-reported health status, number of medical conditions diagnosed by a doctor, number of difficulties performing ADLs and IALDs, employment status, total number of years worked, self-rated memory ability, and birth cohorts of both respondents and spouses, household income, number of living children, and year dummies. We cluster standard errors at the household level. 
Table 4. Log of assets, Alzheimer's Disease Polygenic Score (AD PGS), and Parental History of Memory-related Disease, by asset type

\begin{tabular}{|c|c|c|c|c|c|c|c|}
\hline AD PGS & Financial assets & Stocks & Cash & IRA & CD & Bonds & Other \\
\hline \multicolumn{8}{|l|}{ Respondent factors } \\
\hline Own AD PGS & $\begin{array}{l}-0.0428 \\
(0.0265)\end{array}$ & $\begin{array}{c}-0.1345^{* *} \\
(0.0487)\end{array}$ & $\begin{array}{l}-0.0050 \\
(0.0227)\end{array}$ & $\begin{array}{c}-0.1731 * * \\
(0.0533)\end{array}$ & $\begin{array}{l}0.0982 * \\
(0.0412)\end{array}$ & $\begin{array}{l}-0.0257 \\
(0.0284)\end{array}$ & $\begin{array}{l}-0.0620 \\
(0.0321)\end{array}$ \\
\hline Own Parents MRD & $\begin{array}{c}0.1863 * * \\
(0.0668)\end{array}$ & $\begin{array}{c}0.0656 \\
(0.1280)\end{array}$ & $\begin{array}{c}0.1899 * * \\
(0.0584)\end{array}$ & $\begin{array}{c}0.0855 \\
(0.1383)\end{array}$ & $\begin{array}{c}0.0485 \\
(0.1025)\end{array}$ & $\begin{array}{c}0.0745 \\
(0.0705)\end{array}$ & $\begin{array}{r}0.3805^{* * *} \\
(0.0933)\end{array}$ \\
\hline Own AD PGS*Parents MRD & $\begin{array}{l}-0.0798 \\
(0.0614)\end{array}$ & $\begin{array}{c}0.1319 \\
(0.1236)\end{array}$ & $\begin{array}{l}-0.0373 \\
(0.0525)\end{array}$ & $\begin{array}{c}0.1297 \\
(0.1352)\end{array}$ & $\begin{array}{l}-0.0424 \\
(0.0978)\end{array}$ & $\begin{array}{l}-0.0248 \\
(0.0647)\end{array}$ & $\begin{array}{l}-0.0570 \\
(0.0936)\end{array}$ \\
\hline \multicolumn{8}{|l|}{ Spouse factors } \\
\hline Spouse AD PGS & $\begin{array}{l}-0.0288 \\
(0.0289)\end{array}$ & $\begin{array}{l}-0.0762 \\
(0.0561)\end{array}$ & $\begin{array}{c}0.0138 \\
(0.0249)\end{array}$ & $\begin{array}{c}-0.1762 * * \\
(0.0615)\end{array}$ & $\begin{array}{c}0.0570 \\
(0.0470)\end{array}$ & $\begin{array}{l}-0.0105 \\
(0.0322)\end{array}$ & $\begin{array}{l}-0.0537 \\
(0.0370)\end{array}$ \\
\hline Spouse’s Parents MRD & $\begin{array}{c}0.3001 * * * \\
(0.0674)\end{array}$ & $\begin{array}{c}0.2820 \\
(0.1313)\end{array}$ & $\begin{array}{c}0.2412 * * * \\
(0.0581)\end{array}$ & $\begin{array}{l}0.2925^{*} \\
(0.1436)\end{array}$ & $\begin{array}{c}0.1573 \\
(0.1046)\end{array}$ & $\begin{array}{c}0.0629 \\
(0.0716)\end{array}$ & $\begin{array}{c}0.3609 * * * \\
(0.0951)\end{array}$ \\
\hline Spouse AD PGS*Parents MRD & $\begin{array}{l}-0.1214 \\
(0.0667)\end{array}$ & $\begin{array}{c}0.0680 \\
(0.1372)\end{array}$ & $\begin{array}{l}-0.0940 \\
(0.0561)\end{array}$ & $\begin{array}{c}0.0958 \\
(0.1518)\end{array}$ & $\begin{array}{l}-0.0624 \\
(0.1114)\end{array}$ & $\begin{array}{l}-0.0140 \\
(0.0688)\end{array}$ & $\begin{array}{l}-0.0463 \\
(0.1036)\end{array}$ \\
\hline Constant & $\begin{array}{c}2.2642 \\
(1.3468)\end{array}$ & $\begin{array}{l}-7.2609 * \\
(2.8188)\end{array}$ & $\begin{array}{c}1.3061 \\
(1.4910)\end{array}$ & $\begin{array}{c}-11.5182 * * * \\
(2.7839)\end{array}$ & $\begin{array}{l}-5.9036^{*} \\
(2.5724)\end{array}$ & $\begin{array}{c}-8.8971 * * * \\
(1.7882)\end{array}$ & $\begin{array}{l}-5.0189 * \\
(2.2366)\end{array}$ \\
\hline $\mathrm{R}^{2}$ & 0.2655 & 0.1620 & 0.1422 & 0.1479 & 0.0682 & 0.0806 & 0.0766 \\
\hline
\end{tabular}

Notes: N(household-year)=45,245. N(persons)=8,787. Random effects model coefficients. Robust standard errors in parentheses. *, $* *$, *** denote coefficients that differ from zero with $\mathrm{p}<0.05, \mathrm{p}<0.01$, and $\mathrm{p}<0.001$ respectively. We control for the first ten principal components of the genetic data, age, age-squared, education, self-reported health status, number of medical conditions diagnosed by a doctor, number of difficulties with performing ADLs and IALDs, employment status, total number of years worked, self-rated memory ability, and birth cohorts of both respondents and spouses, household income, number of living children, and year dummies. We cluster standard errors at the household level. 
Table 5. Log of assets, Alzheimer’s Disease Polygenic Score (AD PGS), Cognition PGS, and Total Cognition Score, by asset type

\begin{tabular}{|c|c|c|c|c|c|c|c|}
\hline AD PGS & $\begin{array}{c}\text { Financial } \\
\text { assets }\end{array}$ & Stocks & Cash & IRA & CD & Bonds & Other \\
\hline \multicolumn{8}{|l|}{ Respondent factors } \\
\hline Own AD PGS & $\begin{array}{c}-0.0652 * \\
(0.0310)\end{array}$ & $\begin{array}{l}-0.1141 \\
(0.0585)\end{array}$ & $\begin{array}{l}-0.0398 \\
(0.0281)\end{array}$ & $\begin{array}{c}-0.1562 * \\
(0.0639)\end{array}$ & $\begin{array}{l}0.1322 * \\
(0.0523 \\
)\end{array}$ & $\begin{array}{l}-0.0033 \\
(0.0366)\end{array}$ & $\begin{array}{c}-0.0843^{*} \\
(0.0388)\end{array}$ \\
\hline Own Cognition PGS & $\begin{array}{l}-0.0336 \\
(0.0315)\end{array}$ & $\begin{array}{l}-0.0287 \\
(0.0654)\end{array}$ & $\begin{array}{l}-0.0319 \\
(0.0274)\end{array}$ & $\begin{array}{l}-0.0049 \\
(0.0677)\end{array}$ & $\begin{array}{c}-0.0352 \\
(0.0545 \\
)\end{array}$ & $\begin{array}{l}-0.0020 \\
(0.0391)\end{array}$ & $\begin{array}{c}-0.0197 \\
(0.0439)\end{array}$ \\
\hline Own AD PGS*cognition PGS & $\begin{array}{c}0.0258 \\
(0.0281)\end{array}$ & $\begin{array}{l}-0.0536 \\
(0.0597)\end{array}$ & $\begin{array}{c}0.0151 \\
(0.0240)\end{array}$ & $\begin{array}{l}-0.0195 \\
(0.0632)\end{array}$ & $\begin{array}{c}0.0602 \\
(0.0490 \\
)\end{array}$ & $\begin{array}{c}0.0484 \\
(0.0379)\end{array}$ & $\begin{array}{c}0.0059 \\
(0.0394)\end{array}$ \\
\hline Own Cognition & $\begin{array}{c}0.1048 * * * \\
(0.0227)\end{array}$ & $\begin{array}{c}0.2029 * * * \\
(0.0461)\end{array}$ & $\begin{array}{c}0.1407 * * \\
* \\
(0.0283)\end{array}$ & $\begin{array}{c}0.1190 * * \\
(0.0425)\end{array}$ & $\begin{array}{c}0.1095 * \\
(0.0451 \\
)\end{array}$ & $\begin{array}{c}0.0561 \\
(0.0349)\end{array}$ & $\begin{array}{c}0.1499 * * \\
* \\
(0.0400)\end{array}$ \\
\hline Own AD PGS*cognition & $\begin{array}{l}-0.0083 \\
(0.0206)\end{array}$ & $\begin{array}{l}-0.0087 \\
(0.8312)\end{array}$ & $\begin{array}{c}0.0183 \\
(0.0240)\end{array}$ & $\begin{array}{c}0.0208 \\
(0.0414)\end{array}$ & $\begin{array}{c}-0.0334 \\
(0.0411 \\
)\end{array}$ & $\begin{array}{c}0.0102 \\
(0.0289)\end{array}$ & $\begin{array}{c}-0.0058 \\
(0.0353)\end{array}$ \\
\hline \multicolumn{8}{|l|}{ Spouse factors } \\
\hline Spouse AD PGS & $\begin{array}{c}-0.0428 \\
(0.0340)\end{array}$ & $\begin{array}{l}-0.0670 \\
(0.0673)\end{array}$ & $\begin{array}{l}-0.0175 \\
(0.0305)\end{array}$ & $\begin{array}{l}-0.1715^{*} \\
(0.0735)\end{array}$ & $\begin{array}{c}0.0718 \\
(0.0596 \\
)\end{array}$ & $\begin{array}{c}0.0144 \\
(0.0421)\end{array}$ & $\begin{array}{c}-0.0915 * \\
(0.0446)\end{array}$ \\
\hline Spouse Cognition PGS & $\begin{array}{l}-0.0175 \\
(0.0357)\end{array}$ & $\begin{array}{l}-0.0430 \\
(0.0778)\end{array}$ & $\begin{array}{l}-0.0199 \\
(0.0309)\end{array}$ & $\begin{array}{l}-0.0237 \\
(0.0817)\end{array}$ & $\begin{array}{c}-0.0487 \\
(0.0637 \\
)\end{array}$ & $\begin{array}{l}-0.0137 \\
(0.0459)\end{array}$ & $\begin{array}{l}-0.0439 \\
(0.0520)\end{array}$ \\
\hline $\begin{array}{l}\text { Spouse AD PGS*cognition } \\
\text { PGS }\end{array}$ & $\begin{array}{c}0.0323 \\
(0.0324)\end{array}$ & $\begin{array}{l}-0.0444 \\
(0.0700)\end{array}$ & $\begin{array}{c}0.0144 \\
(0.0270)\end{array}$ & $\begin{array}{l}-0.0064 \\
(0.0726)\end{array}$ & $\begin{array}{c}0.0542 \\
(0.0569 \\
)\end{array}$ & $\begin{array}{c}0.0593 \\
(0.0427)\end{array}$ & $\begin{array}{l}-0.0084 \\
(0.0453)\end{array}$ \\
\hline Spouse Cognition & $\begin{array}{c}0.0909 * * * \\
(0.0201)\end{array}$ & $\begin{array}{c}0.1768 * * * \\
(0.0413)\end{array}$ & $\begin{array}{c}0.1079 * * \\
* \\
(0.0253)\end{array}$ & $\begin{array}{c}0.1711^{* * *} \\
(0.0383)\end{array}$ & $\begin{array}{c}0.0675 \\
(0.0400 \\
)\end{array}$ & $\begin{array}{l}0.0616 * \\
(0.0306)\end{array}$ & $\begin{array}{c}0.1532 * * \\
* \\
(0.0352)\end{array}$ \\
\hline
\end{tabular}




\begin{tabular}{|c|c|c|c|c|c|c|c|}
\hline Spouse AD PGS*cognition & $\begin{array}{c}-0.0127 \\
(0.0205)\end{array}$ & $\begin{array}{l}-0.0016 \\
(0.0415)\end{array}$ & $\begin{array}{c}0.0092 \\
(0.0242)\end{array}$ & $\begin{array}{c}0.0207 \\
(0.0428)\end{array}$ & $\begin{array}{r}-0.0592 \\
(0.0416\end{array}$ & $\begin{array}{c}0.0086 \\
(0.0290)\end{array}$ & $\begin{array}{c}-0.0177 \\
(0.0368)\end{array}$ \\
\hline Constant & $\begin{array}{c}1.9983 \\
(1.8583)\end{array}$ & $\begin{array}{c}- \\
14.1316^{* * *} \\
(4.1760) \\
\end{array}$ & $\begin{array}{c}-0.0433 \\
(2.2911)\end{array}$ & $\begin{array}{c}- \\
13.8285^{* *} \\
(4.2296) \\
\end{array}$ & $\begin{array}{c}\text { ) } \\
-4.6046 \\
(4.2210 \\
) \\
\end{array}$ & $\begin{array}{c}- \\
11.4493 * * * \\
(2.9440) \\
\end{array}$ & $\begin{array}{c}-0.4248 \\
(3.6596)\end{array}$ \\
\hline $\mathrm{R}^{2}$ & 0.2494 & 0.1742 & 0.1276 & 0.1404 & 0.0629 & 0.1015 & 0.0862 \\
\hline
\end{tabular}

Notes: N(household-year)=24,038. N(persons)=5,678. Random effects model coefficients. Robust standard errors in parentheses. *, $* *$, *** denote coefficients that differ from zero with $\mathrm{p}<0.05, \mathrm{p}<0.01$, and $\mathrm{p}<0.001$ respectively. We control for the first ten principal components of the genetic data, age, age-squared, education, self-reported health status, number of medical conditions diagnosed by a doctor, number of difficulties with performing ADLs and IALDs, employment status, total number of years worked, self-rated memory ability, and birth cohorts of both respondents and spouses, household income, number of living children, and year dummies. We cluster standard errors at the household level. 
Table 6. Log of assets, Alzheimer's Disease Polygenic Score (AD PGS), and Age, by asset type

\begin{tabular}{|c|c|c|c|c|c|c|c|}
\hline AD PGS & Financial assets & Stocks & Cash & IRA & CD & Bonds & Other \\
\hline \multicolumn{8}{|l|}{ Respondent factors } \\
\hline Own AD PGS & $\begin{array}{l}-0.0856 \\
(0.6304)\end{array}$ & $\begin{array}{c}-4.3605 * * \\
(1.4103)\end{array}$ & $\begin{array}{l}-0.0013 \\
(0.7468)\end{array}$ & $\begin{array}{c}0.6114 \\
(1.3857)\end{array}$ & $\begin{array}{l}-0.9840 \\
(1.2910)\end{array}$ & $\begin{array}{l}-1.2744 \\
(0.8777)\end{array}$ & $\begin{array}{l}-1.9867 \\
(1.1147)\end{array}$ \\
\hline Own age & $\begin{array}{c}0.0344 \\
(0.0277)\end{array}$ & $\begin{array}{c}0.0365 \\
(0.0571)\end{array}$ & $\begin{array}{c}0.0070 \\
(0.0317)\end{array}$ & $\begin{array}{c}0.1927 * * * \\
(0.0552)\end{array}$ & $\begin{array}{c}0.0794 \\
(0.0527)\end{array}$ & $\begin{array}{l}0.0872^{*} \\
(0.0358)\end{array}$ & $\begin{array}{r}0.0870 \\
(0.0467)\end{array}$ \\
\hline Own AD PGS*age & $\begin{array}{c}0.0025 \\
(0.0186)\end{array}$ & $\begin{array}{c}0.1252^{* *} \\
(0.0423)\end{array}$ & $\begin{array}{c}0.0028 \\
(0.0224)\end{array}$ & $\begin{array}{l}-0.0220 \\
(0.0411)\end{array}$ & $\begin{array}{c}0.0303 \\
(0.0391)\end{array}$ & $\begin{array}{c}0.0346 \\
(0.0264)\end{array}$ & $\begin{array}{c}0.0582 \\
(0.0330)\end{array}$ \\
\hline Own age ${ }^{2}$ & $\begin{array}{l}-0.0785 \\
(0.1897)\end{array}$ & $\begin{array}{l}-0.0385 \\
(0.3993)\end{array}$ & $\begin{array}{c}0.1724 \\
(0.2243)\end{array}$ & $\begin{array}{c}-1.5541 * * * \\
(0.3783)\end{array}$ & $\begin{array}{l}-0.1391 \\
(0.3748)\end{array}$ & $\begin{array}{l}-0.4527 \\
(0.2561)\end{array}$ & $\begin{array}{l}-0.8203^{*} \\
(0.3278)\end{array}$ \\
\hline Own AD PGS*age ${ }^{2}$ & $\begin{array}{c}-0.0301 \\
(0.1348)\end{array}$ & $\begin{array}{c}-0.9044^{* *} \\
(0.3126)\end{array}$ & $\begin{array}{c}-0.0440 \\
(0.1653)\end{array}$ & $\begin{array}{c}0.1545 \\
(0.3007)\end{array}$ & $\begin{array}{l}-0.2082 \\
(0.2922)\end{array}$ & $\begin{array}{l}-0.2335 \\
(0.1964)\end{array}$ & $\begin{array}{c}-0.4338 \\
(0.2407)\end{array}$ \\
\hline \multicolumn{8}{|l|}{ Spouse factors } \\
\hline Spouse AD PGS & $\begin{array}{c}0.0454 \\
(0.5499)\end{array}$ & $\begin{array}{l}-1.2306 \\
(1.3028)\end{array}$ & $\begin{array}{l}-0.2796 \\
(0.6305)\end{array}$ & $\begin{array}{c}0.2364 \\
(1.2705)\end{array}$ & $\begin{array}{l}-0.7217 \\
(1.1095)\end{array}$ & $\begin{array}{l}-0.0254 \\
(0.6712)\end{array}$ & $\begin{array}{c}-0.8722 \\
(1.0526)\end{array}$ \\
\hline Spouse age & $\begin{array}{c}0.0288 \\
(0.0231)\end{array}$ & $\begin{array}{c}0.0245 \\
(0.0448)\end{array}$ & $\begin{array}{l}-0.0118 \\
(0.0234)\end{array}$ & $\begin{array}{c}0.2354 * * * \\
(0.0425)\end{array}$ & $\begin{array}{l}-0.0070 \\
(0.0376)\end{array}$ & $\begin{array}{c}0.0809 * * * \\
(0.0243)\end{array}$ & $\begin{array}{l}-0.0263 \\
(0.0354)\end{array}$ \\
\hline Spouse AD PGS*age & $\begin{array}{l}-0.0027 \\
(0.0165)\end{array}$ & $\begin{array}{c}0.0342 \\
(0.0396)\end{array}$ & $\begin{array}{c}0.0094 \\
(0.0194)\end{array}$ & $\begin{array}{l}-0.0102 \\
(0.0383)\end{array}$ & $\begin{array}{c}0.0229 \\
(0.0342)\end{array}$ & $\begin{array}{l}-0.0024 \\
(0.0209)\end{array}$ & $\begin{array}{r}0.0286 \\
(0.0317)\end{array}$ \\
\hline Spouse age ${ }^{2}$ & $\begin{array}{l}-0.0650 \\
(0.1584)\end{array}$ & $\begin{array}{c}0.1106 \\
(0.3169)\end{array}$ & $\begin{array}{c}0.1877 \\
(0.1653)\end{array}$ & $\begin{array}{c}-1.8054 * * * \\
(0.2930)\end{array}$ & $\begin{array}{c}0.4579 \\
(0.2714)\end{array}$ & $\begin{array}{l}-0.3908 * \\
(0.1793)\end{array}$ & $\begin{array}{c}0.1321 \\
(0.2495)\end{array}$ \\
\hline Spouse AD PGS*age ${ }^{2}$ & $\begin{array}{c}0.0186 \\
(0.1216)\end{array}$ & $\begin{array}{l}-0.2437 \\
(0.2977)\end{array}$ & $\begin{array}{l}-0.0767 \\
(0.1464)\end{array}$ & $\begin{array}{c}0.0628 \\
(0.2852)\end{array}$ & $\begin{array}{l}-0.1665 \\
(0.2598)\end{array}$ & $\begin{array}{c}0.0396 \\
(0.1600)\end{array}$ & $\begin{array}{l}-0.2415 \\
(0.2353)\end{array}$ \\
\hline Constant & $\begin{array}{c}2.6153 \\
(1.3475)\end{array}$ & $\begin{array}{c}-7.2680 * * \\
(2.8103)\end{array}$ & $\begin{array}{c}1.6300 \\
(1.4927)\end{array}$ & $\begin{array}{c}-11.2468 * * * \\
(2.7820)\end{array}$ & $\begin{array}{l}-5.8652 * \\
(2.5690)\end{array}$ & $\begin{array}{c}-8.8261 * * * \\
(1.7821)\end{array}$ & $\begin{array}{l}-4.5604^{*} \\
(2.2339)\end{array}$ \\
\hline " Own AD PGS joint Chi²(3) & 5.77 & $16.21 * *$ & 3.20 & $9.60^{*}$ & 6.46 & 6.07 & $9.23^{*}$ \\
\hline Spouse AD PGS joint $\mathrm{Chi}^{2}(3)$ & 3.36 & 2.36 & 0.42 & 7.64 & 1.66 & 1.93 & 5.77 \\
\hline $\mathrm{R}^{2}$ & 0.2634 & 0.1615 & 0.1412 & 0.1469 & 0.0681 & 0.0806 & 0.0746 \\
\hline
\end{tabular}

Notes: N(household-year)=45,245. N(persons)=8,787. Random effects model coefficients. Robust standard errors in parentheses. Agesquared is divided by $1,000 . *$, **, *** denote coefficients that differ from zero with $\mathrm{p}<0.05, \mathrm{p}<0.01$, and $\mathrm{p}<0.001$ respectively. We control for the first ten principal components of the genetic data, age-squared, education, self-reported health status, number of 
medical conditions diagnosed by a doctor, number of difficulties with performing ADLs and IALDs, employment status, total number of years worked, self-rated memory ability, and birth cohorts of both respondents and spouses, household income, number of living children, and year dummies. We cluster standard errors at the household level. 
Table 7. Log of assets, Alzheimer's Disease Polygenic Score (AD PGS), and Self-rated Memory, by asset type

\begin{tabular}{|c|c|c|c|c|c|c|c|}
\hline AD PGS & Financial assets & Stocks & Cash & IRA & CD & Bonds & Other \\
\hline \multicolumn{8}{|l|}{ Respondent factors } \\
\hline Own AD PGS & $\begin{array}{l}-0.0549 * \\
(0.0244)\end{array}$ & $\begin{array}{l}-0.1145^{*} \\
(0.0450)\end{array}$ & $\begin{array}{l}-0.0109 \\
(0.0209)\end{array}$ & $\begin{array}{c}-0.1508 * * \\
(0.0493)\end{array}$ & $\begin{array}{l}0.0920^{*} \\
(0.0376)\end{array}$ & $\begin{array}{l}-0.0292 \\
(0.0259)\end{array}$ & $\begin{array}{l}-0.0698 * \\
(0.0302)\end{array}$ \\
\hline Own self-rated memory & $\begin{array}{c}0.0050 \\
(0.0143)\end{array}$ & $\begin{array}{l}-0.0001 \\
(0.0278)\end{array}$ & $\begin{array}{l}-0.0022 \\
(0.0172)\end{array}$ & $\begin{array}{l}-0.0073 \\
(0.0268)\end{array}$ & $\begin{array}{c}0.0033 \\
(0.0264)\end{array}$ & $\begin{array}{l}-0.0187 \\
(0.0193)\end{array}$ & $\begin{array}{r}0.0686 * * \\
(0.0255)\end{array}$ \\
\hline $\begin{array}{l}\text { Own AD PGS*self-rated } \\
\text { memory }\end{array}$ & $\begin{array}{c}0.0028 \\
(0.0143)\end{array}$ & $\begin{array}{c}0.0078 \\
(0.0263)\end{array}$ & $\begin{array}{c}0.0050 \\
(0.0163)\end{array}$ & $\begin{array}{l}-0.0175 \\
(0.0261)\end{array}$ & $\begin{array}{l}-0.0139 \\
(0.0254)\end{array}$ & $\begin{array}{l}-0.0030 \\
(0.0191)\end{array}$ & $\begin{array}{c}0.0029 \\
(0.0244)\end{array}$ \\
\hline \multicolumn{8}{|l|}{ Spouse factors } \\
\hline Spouse AD PGS & $\begin{array}{l}-0.0481 \\
(0.0265)\end{array}$ & $\begin{array}{l}-0.0618 \\
(0.0519)\end{array}$ & $\begin{array}{l}-0.0013 \\
(0.0228)\end{array}$ & $\begin{array}{c}-0.1565 * * \\
(0.0571)\end{array}$ & $\begin{array}{c}0.0482 \\
(0.0429)\end{array}$ & $\begin{array}{l}-0.0123 \\
(0.0291)\end{array}$ & $\begin{array}{l}-0.0603 \\
(0.0348)\end{array}$ \\
\hline Spouse self-rated memory & $\begin{array}{c}0.0021 \\
(0.0138)\end{array}$ & $\begin{array}{l}-0.0097 \\
(0.0270)\end{array}$ & $\begin{array}{c}0.0120 \\
(0.0166)\end{array}$ & $\begin{array}{c}0.0148 \\
(0.0260)\end{array}$ & $\begin{array}{l}-0.0067 \\
(0.0253)\end{array}$ & $\begin{array}{l}-0.0126 \\
(0.0182)\end{array}$ & $\begin{array}{r}0.0685 * * \\
(0.0243)\end{array}$ \\
\hline $\begin{array}{l}\text { Spouse AD PGS*self-rated } \\
\text { memory }\end{array}$ & $\begin{array}{c}0.0023 \\
(0.0149)\end{array}$ & $\begin{array}{c}0.0156 \\
(0.0287)\end{array}$ & $\begin{array}{c}0.0079 \\
(0.0175)\end{array}$ & $\begin{array}{l}-0.0279 \\
(0.0289)\end{array}$ & $\begin{array}{l}-0.0187 \\
(0.0272)\end{array}$ & $\begin{array}{l}-0.0105 \\
(0.0202)\end{array}$ & $\begin{array}{l}-0.0111 \\
(0.0267)\end{array}$ \\
\hline Constant & $\begin{array}{c}2.6077 \\
(1.3445)\end{array}$ & $\begin{array}{l}-7.0799 \\
(2.8142)\end{array}$ & $\begin{array}{c}1.6374 \\
(1.4907)\end{array}$ & $\begin{array}{c}-11.2802 * * * \\
(2.7802)\end{array}$ & $\begin{array}{l}-5.7821 \\
(2.5663)\end{array}$ & $\begin{array}{c}-8.7870 * * * \\
(1.7811)\end{array}$ & $\begin{array}{l}-4.4442 * \\
(2.2363)\end{array}$ \\
\hline$\overline{\mathrm{R}^{2}}$ & 0.2634 & 0.1617 & 0.1411 & 0.1472 & 0.0680 & 0.0805 & 0.0745 \\
\hline
\end{tabular}

Notes: N(household-year)=45,245. N(persons)=8,787. Random effects model coefficients. Robust standard errors in parentheses. $*$, $* *$, *** denote coefficients that differ from zero with $\mathrm{p}<0.05, \mathrm{p}<0.01$, and $\mathrm{p}<0.001$ respectively. We control for the first ten principal components of the genetic data, age, age-squared, education, self-reported health status, number of medical conditions diagnosed by a doctor, number of difficulties with performing ADLs and IALDs, employment status, total number of years worked, and birth cohorts of both respondents and spouses, household income, number of living children, and year dummies. We cluster standard errors at the household level. 
Table 8. Log of assets, Alzheimer’s Disease Polygenic Score (AD PGS), and Risk Aversion, by asset type

\begin{tabular}{|c|c|c|c|c|c|c|c|}
\hline AD PGS & Financial assets & Stocks & Cash & IRA & CD & Bonds & Other \\
\hline \multicolumn{8}{|l|}{ Respondent factors } \\
\hline Own AD PGS & $\begin{array}{c}-0.0404 \\
(0.0315)\end{array}$ & $\begin{array}{c}-0.0986 \\
(0.0580)\end{array}$ & $\begin{array}{c}0.0148 \\
(0.0272)\end{array}$ & $\begin{array}{l}-0.1340 * \\
(0.0638)\end{array}$ & $\begin{array}{c}0.0743 \\
(0.0477)\end{array}$ & $\begin{array}{c}-0.0352 \\
(0.0313)\end{array}$ & $\begin{array}{c}-0.0812 * \\
(0.0402)\end{array}$ \\
\hline Own Risk aversion & $\begin{array}{c}-0.0650 \\
(0.0434)\end{array}$ & $\begin{array}{c}-0.0463 \\
(0.0924)\end{array}$ & $\begin{array}{l}-0.0586 \\
(0.0463)\end{array}$ & $\begin{array}{c}-0.0516 \\
(0.0975)\end{array}$ & $\begin{array}{c}0.0926 \\
(0.0790)\end{array}$ & $\begin{array}{c}-0.0334 \\
(0.0533)\end{array}$ & $\begin{array}{c}-0.1206 \\
(0.0785)\end{array}$ \\
\hline \multicolumn{8}{|l|}{ Spouse factors } \\
\hline Spouse AD PGS & $\begin{array}{c}-0.0288 \\
(0.0332)\end{array}$ & $\begin{array}{c}-0.0629 \\
(0.0649)\end{array}$ & $\begin{array}{c}0.0116 \\
(0.0288)\end{array}$ & $\begin{array}{l}-0.1015 \\
(0.0714)\end{array}$ & $\begin{array}{c}0.0852 \\
(0.0537)\end{array}$ & $\begin{array}{c}-0.0207 \\
(0.0347)\end{array}$ & $\begin{array}{l}-0.0445 \\
(0.0453)\end{array}$ \\
\hline Spouse Risk aversion & $\begin{array}{c}0.0186 \\
(0.0439)\end{array}$ & $\begin{array}{l}-0.1089 \\
(0.0969)\end{array}$ & $\begin{array}{c}0.0199 \\
(0.0469)\end{array}$ & $\begin{array}{c}0.0841 \\
(0.0999)\end{array}$ & $\begin{array}{c}0.1095 \\
(0.0817)\end{array}$ & $\begin{array}{c}0.0281 \\
(0.0535)\end{array}$ & $\begin{array}{l}-0.0163 \\
(0.0790)\end{array}$ \\
\hline Constant & $\begin{array}{l}4.2793 * \\
(2.0276) \\
\end{array}$ & $\begin{array}{c}-7.2286 \\
(4.0974) \\
\end{array}$ & $\begin{array}{c}3.6484 \\
(2.2354) \\
\end{array}$ & $\begin{array}{c}-11.1996 * * \\
(4.0117) \\
\end{array}$ & $\begin{array}{r}-5.8099 \\
(3.7810) \\
\end{array}$ & $\begin{array}{c}-8.0167 * * \\
(2.5299) \\
\end{array}$ & $\begin{array}{r}-2.8658 \\
(3.2241) \\
\end{array}$ \\
\hline$\overline{\mathrm{R}^{2}}$ & 0.2851 & 0.1603 & 0.1566 & 0.1588 & 0.0637 & 0.0679 & 0.0770 \\
\hline
\end{tabular}

Notes: N(household-year)=26,842. N(persons)=4,908. Random effects model coefficients. Robust standard errors in parentheses. *, $* *$, *** denote coefficients that differ from zero with $\mathrm{p}<0.05, \mathrm{p}<0.01$, and $\mathrm{p}<0.001$ respectively. We control for the first ten principal components of the genetic data, age, age-squared, education, self-reported health status, number of medical conditions diagnosed by a doctor, number of difficulties with performing ADLs and IALDs, employment status, total number of years worked, self-rated memory ability, and birth cohorts of both respondents and spouses, household income, number of living children, and year dummies. We cluster standard errors at the household level. 
Table 9. Log of assets, Alzheimer’s Disease Polygenic Score (AD PGS), and Planning Horizon, by asset type

\begin{tabular}{|c|c|c|c|c|c|c|c|}
\hline AD PGS & Financial assets & Stocks & Cash & IRA & CD & Bonds & Other \\
\hline \multicolumn{8}{|l|}{ Respondent factors } \\
\hline Own AD PGS & $\begin{array}{l}-0.0559 * \\
(0.0255)\end{array}$ & $\begin{array}{l}-0.1038^{*} \\
(0.0494)\end{array}$ & $\begin{array}{l}-0.0107 \\
(0.0224)\end{array}$ & $\begin{array}{c}-0.1450 * * \\
(0.0526)\end{array}$ & $\begin{array}{c}0.1147 * * \\
(0.0417)\end{array}$ & $\begin{array}{l}-0.0285 \\
(0.0284)\end{array}$ & $\begin{array}{l}-0.0664 \\
(0.0356)\end{array}$ \\
\hline \multicolumn{8}{|l|}{ Own planning horizon } \\
\hline Next year & $\begin{array}{c}0.2604 * * * \\
(0.0622)\end{array}$ & $\begin{array}{c}0.0080 \\
(0.1183)\end{array}$ & $\begin{array}{c}0.2417 * * * \\
(0.0719)\end{array}$ & $\begin{array}{c}0.1461 \\
(0.1214)\end{array}$ & $\begin{array}{c}0.0932 \\
(0.1099)\end{array}$ & $\begin{array}{l}-0.1057 \\
(0.0689)\end{array}$ & $\begin{array}{c}0.2689 * * \\
(0.1006)\end{array}$ \\
\hline Next few years & $\begin{array}{c}0.3947 * * * \\
(0.0544)\end{array}$ & $\begin{array}{c}0.4235^{* * * *} \\
(0.1026)\end{array}$ & $\begin{array}{c}0.3724 * * * \\
(0.0610)\end{array}$ & $\begin{array}{c}0.3931 * * * \\
(0.1021)\end{array}$ & $\begin{array}{c}0.2858 * * \\
(0.0926)\end{array}$ & $\begin{array}{c}0.0038 \\
(0.0593)\end{array}$ & $\begin{array}{l}0.2101^{*} \\
(0.0838)\end{array}$ \\
\hline Next 5-10 years & $\begin{array}{c}0.4215 * * * \\
(0.0542)\end{array}$ & $\begin{array}{c}0.4304 * * * \\
(0.1029)\end{array}$ & $\begin{array}{c}0.4719 * * * \\
(0.0598)\end{array}$ & $\begin{array}{c}0.5276^{* * * *} \\
(0.1009)\end{array}$ & $\begin{array}{c}0.2528 * * \\
(0.0924)\end{array}$ & $\begin{array}{c}0.0520 \\
(0.0592)\end{array}$ & $\begin{array}{c}0.3000 * * * \\
(0.0846)\end{array}$ \\
\hline Longer than 10 years & $\begin{array}{c}0.4233 * * * \\
(0.0619)\end{array}$ & $\begin{array}{c}0.5462 * * * \\
(0.1323)\end{array}$ & $\begin{array}{c}0.3932 * * * \\
(0.0720)\end{array}$ & $\begin{array}{c}0.5172 * * * \\
(0.1192)\end{array}$ & $\begin{array}{c}0.3112^{* *} \\
(0.1149)\end{array}$ & $\begin{array}{c}0.1182 \\
(0.0786)\end{array}$ & $\begin{array}{c}0.4051^{* * *} \\
(0.1118)\end{array}$ \\
\hline \multicolumn{8}{|l|}{ Spouse factors } \\
\hline Own AD PGS & $\begin{array}{l}-0.0477 \\
(0.0270)\end{array}$ & $\begin{array}{l}-0.0542 \\
(0.0552)\end{array}$ & $\begin{array}{c}0.0042 \\
(0.0241)\end{array}$ & $\begin{array}{l}-0.1390 * \\
(0.0585)\end{array}$ & $\begin{array}{c}0.0848 \\
(0.0467)\end{array}$ & $\begin{array}{l}-0.0131 \\
(0.0316)\end{array}$ & $\begin{array}{l}-0.0528 \\
(0.0394)\end{array}$ \\
\hline \multicolumn{8}{|l|}{ Spouse planning horizon } \\
\hline Next year & $\begin{array}{c}0.2460 * * * \\
(0.0631)\end{array}$ & $\begin{array}{c}-0.0362 \\
(0.1171)\end{array}$ & $\begin{array}{c}0.2219 * * \\
(0.0704)\end{array}$ & $\begin{array}{c}0.1755 \\
(0.1187)\end{array}$ & $\begin{array}{c}0.0841 \\
(0.1088)\end{array}$ & $\begin{array}{c}-0.0946 \\
(0.0671)\end{array}$ & $\begin{array}{c}0.2532 * * \\
(0.0982)\end{array}$ \\
\hline Next few years & $\begin{array}{c}0.3342 * * * \\
(0.0539)\end{array}$ & $\begin{array}{c}0.2863 * * \\
(0.1013)\end{array}$ & $\begin{array}{c}0.3272 * * * \\
(0.0587)\end{array}$ & $\begin{array}{c}0.3855 * * * \\
(0.0991)\end{array}$ & $\begin{array}{c}0.2385 * * \\
(0.0920)\end{array}$ & $\begin{array}{c}0.0051 \\
(0.0573)\end{array}$ & $\begin{array}{l}0.1923 * \\
(0.0832)\end{array}$ \\
\hline Next 5-10 years & $\begin{array}{c}0.3706 * * * \\
(0.0541)\end{array}$ & $\begin{array}{c}0.3409 * * * \\
(0.1031)\end{array}$ & $\begin{array}{c}0.3723 * * * \\
(0.0583)\end{array}$ & $\begin{array}{c}0.5707 * * * \\
(0.0980)\end{array}$ & $\begin{array}{l}0.2369 * \\
(0.0922)\end{array}$ & $\begin{array}{c}0.0542 \\
(0.0568)\end{array}$ & $\begin{array}{c}0.2392 * * \\
(0.0834)\end{array}$ \\
\hline Longer than 10 years & $\begin{array}{c}0.3944 * * * \\
(0.0607)\end{array}$ & $\begin{array}{c}0.4634 * * * \\
(0.1279)\end{array}$ & $\begin{array}{c}0.3182 * * * \\
(0.0714)\end{array}$ & $\begin{array}{c}0.5450 * * * \\
(0.1167)\end{array}$ & $\begin{array}{c}0.3719 * * \\
(0.1128)\end{array}$ & $\begin{array}{l}0.1603^{*} \\
(0.0761)\end{array}$ & $\begin{array}{c}0.3496 * * \\
(0.1091)\end{array}$ \\
\hline Constant & $\begin{array}{c}0.4204 \\
(1.7445) \\
\end{array}$ & $\begin{array}{c}-14.5350 * * \\
(5.0322) \\
\end{array}$ & $\begin{array}{c}1.9422 \\
(1.8987) \\
\end{array}$ & $\begin{array}{c}-20.4057^{* * *} \\
(3.8916) \\
\end{array}$ & $\begin{array}{c}-5.0254 \\
(3.4640) \\
\end{array}$ & $\begin{array}{c}-11.8186^{* * *} \\
(3.1359) \\
\end{array}$ & $\begin{array}{c}-10.7417 * * * \\
(3.2450) \\
\end{array}$ \\
\hline $\mathrm{R}^{2}$ & 0.2993 & 0.1691 & 0.1674 & 0.1661 & 0.0786 & 0.0803 & 0.0816 \\
\hline
\end{tabular}

Notes: N(household-year)=27,558. N(persons)=7,900. Random effects model coefficients. Robust standard errors in parentheses. *, $* *$, *** denote coefficients that differ from zero with $\mathrm{p}<0.05, \mathrm{p}<0.01$, and $\mathrm{p}<0.001$ respectively. We control for the first ten principal components of the genetic data, age, age-squared, education, self-reported health status, number of medical conditions diagnosed by a 
doctor, number of difficulties with performing ADLs and IALDs, employment status, total number of years worked, self-rated memory ability, and birth cohorts of both respondents and spouses, household income, number of living children, and year dummies. We cluster standard errors at the household level. 


\section{Appendix}

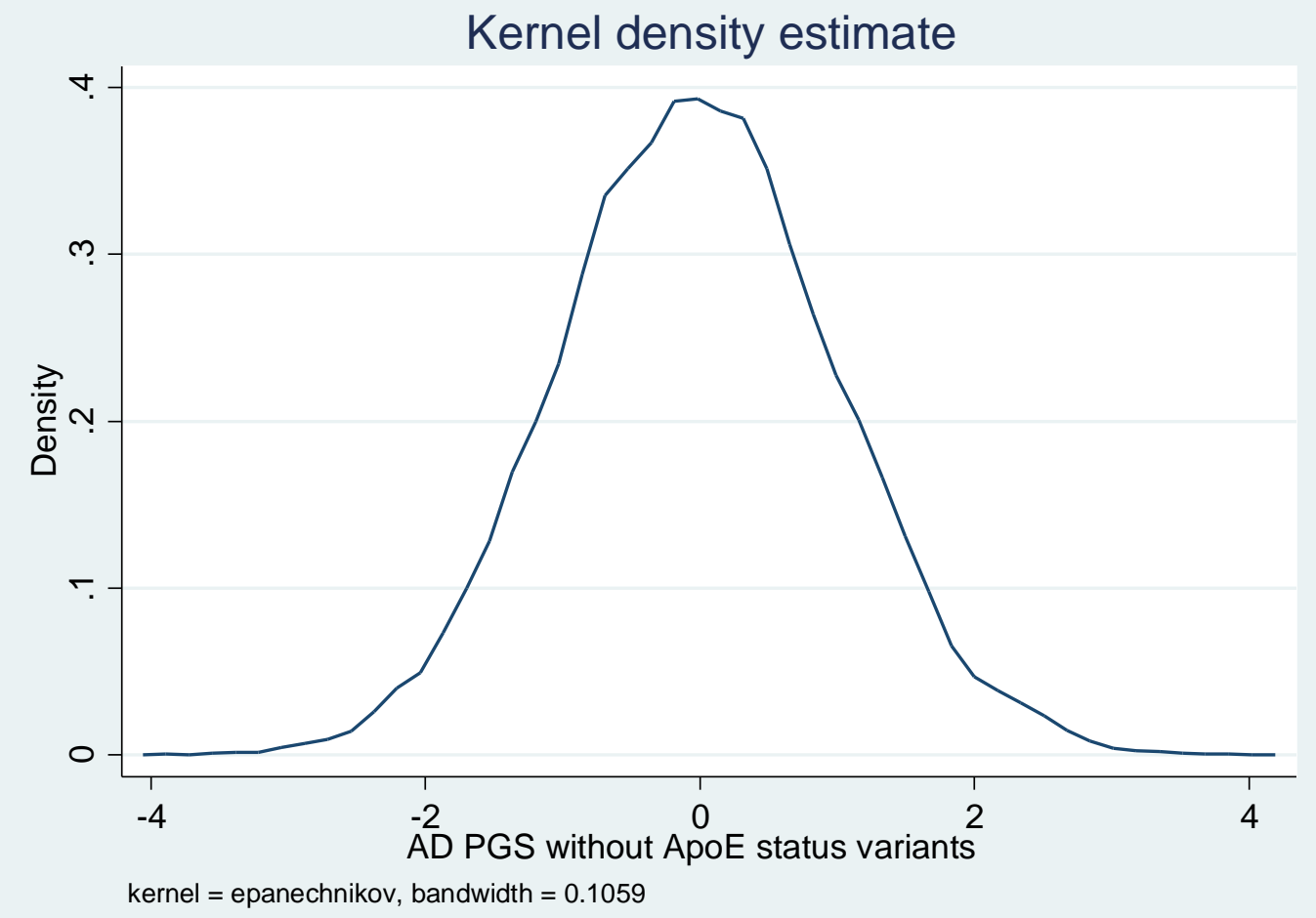

Figure A2. Distribution of Alzheimer's Disease PGS. 
Table A10. Correlation between Alzheimer's Disease Polygenic Score (AD PGS) and Having Parent with History of Memory Related Disease (MRD)

\begin{tabular}{|c|c|c|c|c|}
\hline & \multicolumn{2}{|c|}{ AD PGS $\underline{w / o}$ ApoE variants } & \multicolumn{2}{|c|}{ AD PGS with ApoE variants } \\
\hline & (1) & $(2)$ & $(1)$ & $(2)$ \\
\hline \multicolumn{5}{|l|}{ Parent has MRD } \\
\hline Mother & $\begin{array}{c}-0.0636 \\
(0.0853)\end{array}$ & --- & $\begin{array}{c}-0.0611 \\
(0.0854)\end{array}$ & --- \\
\hline Father & $\begin{array}{c}0.0255 \\
(0.0885)\end{array}$ & --- & $\begin{array}{c}0.0260 \\
(0.0886)\end{array}$ & --- \\
\hline Mother or father & --- & $\begin{array}{c}0.0239 \\
(0.0348)\end{array}$ & --- & $\begin{array}{c}0.0254 \\
(0.0348)\end{array}$ \\
\hline Constant & $\begin{array}{c}0.0040 \\
(0.0467) \\
\end{array}$ & $\begin{array}{c}-0.0188 \\
(0.0130)\end{array}$ & $\begin{array}{c}0.0034 \\
(0.0468) \\
\end{array}$ & $\begin{array}{c}-0.0189 \\
(0.0130)\end{array}$ \\
\hline R-squared & 0.0243 & 0.0320 & 0.0243 & 0.0320 \\
\hline
\end{tabular}

Note. OLS coefficients. Robust standard errors in parentheses. We control for the first ten principal components of the genetic data. We cluster standard errors at the individual level.

Table A11. Correlation between self-rated memory and Alzheimer’s Disease Polygenic Score (AD PGS)

\begin{tabular}{|c|c|c|c|c|c|c|}
\hline & $(1)$ & $(2)$ & (3) & (4) & $(5)$ & $(6)$ \\
\hline AD PGS w/o ApoE & $\begin{array}{c}-0.0275^{* * *} \\
(0.0082)\end{array}$ & $\begin{array}{c}-0.0290 * * * \\
(0.0082)\end{array}$ & & & $\begin{array}{l}1.7412 * * \\
(0.6391)\end{array}$ & $\begin{array}{l}1.9409 * * \\
(0.6390)\end{array}$ \\
\hline AD PGS w/ ApoE & & & $\begin{array}{c}-0.0277 * * * \\
(0.0082)\end{array}$ & $\begin{array}{c}-0.0293 * * * \\
(0.0081)\end{array}$ & $\begin{array}{c}-1.7685^{* * *} \\
(0.6388)\end{array}$ & $\begin{array}{c}-1.9697 * * \\
(0.6387)\end{array}$ \\
\hline Age & & $\begin{array}{c}-0.0183^{* * *} \\
(0.0006)\end{array}$ & & $\begin{array}{c}-0.0183 * * * \\
(0.0006)\end{array}$ & & $\begin{array}{c}-0.0183^{* * *} \\
(0.0006)\end{array}$ \\
\hline Constant & $\begin{array}{c}0.0756^{* * *} \\
(0.0081) \\
\end{array}$ & $\begin{array}{c}1.2746 * * * \\
(0.0426) \\
\end{array}$ & $\begin{array}{c}0.0756 * * * \\
(0.0081) \\
\end{array}$ & $\begin{array}{c}1.2746^{* * *} \\
(0.0426) \\
\end{array}$ & $\begin{array}{c}0.0757 * * * \\
(0.0081) \\
\end{array}$ & $\begin{array}{c}1.2757 * * * \\
(0.0426) \\
\end{array}$ \\
\hline R-squared & 0.0032 & 0.0210 & 0.0033 & 0.0210 & 0.0037 & 0.0216 \\
\hline
\end{tabular}


Note. Random effects model coefficients. Random effects model coefficients. Robust standard errors in parentheses. *, **, *** denote coefficients that differ from zero with $\mathrm{p}<0.05, \mathrm{p}<0.01$, and $\mathrm{p}<0.001$ respectively. We control for the first ten principal components of the genetic data. We cluster standard errors at the individual level. 
Table A12. Log of assets and Alzheimer's Disease Polygenic Score (AD PGS) without ApoE status variants, by asset type

\begin{tabular}{|c|c|c|c|c|c|c|c|}
\hline AD PGS w/o ApoE variants & Financial assets & Stocks & Cash & IRA & CD & Bonds & Other \\
\hline Respondent & $\begin{array}{c}-0.0549^{*} \\
(0.0242)\end{array}$ & $\begin{array}{l}-0.1146^{*} \\
(0.0450)\end{array}$ & $\begin{array}{l}-0.0107 \\
(0.0207)\end{array}$ & $\begin{array}{c}-0.1527 * * \\
(0.0493)\end{array}$ & $\begin{array}{l}0.0906^{*} \\
(0.0376)\end{array}$ & $\begin{array}{l}-0.0293 \\
(0.0259)\end{array}$ & $\begin{array}{l}-0.0693^{*} \\
(0.0303)\end{array}$ \\
\hline Spouse & $\begin{array}{l}-0.0483 \\
(0.0264)\end{array}$ & $\begin{array}{l}-0.0617 \\
(0.0519)\end{array}$ & $\begin{array}{l}-0.0010 \\
(0.0227)\end{array}$ & $\begin{array}{c}-0.1581 * * \\
(0.0571)\end{array}$ & $\begin{array}{c}0.0470 \\
(0.0429)\end{array}$ & $\begin{array}{l}-0.0126 \\
(0.0292)\end{array}$ & $\begin{array}{l}-0.0608 \\
(0.0348)\end{array}$ \\
\hline Constant & $\begin{array}{c}2.6081 \\
(1.3445)\end{array}$ & $\begin{array}{l}-7.0744^{*} \\
(2.8143)\end{array}$ & $\begin{array}{c}1.6408 \\
(1.4910)\end{array}$ & $\begin{array}{c}-11.2900 * * * \\
(2.7801)\end{array}$ & $\begin{array}{l}-5.7891^{*} \\
(2.5663)\end{array}$ & $\begin{array}{c}-8.7919 * * * \\
(1.7809)\end{array}$ & $\begin{array}{l}-4.4503^{*} \\
(2.2366)\end{array}$ \\
\hline$\overline{\mathrm{R}^{2}}$ & 0.2634 & 0.1617 & 0.1411 & 0.1470 & 0.0679 & 0.0805 & 0.0745 \\
\hline
\end{tabular}

Notes: N(household-year)=45,245. N(persons)=8,787. Random effects model coefficients. Robust standard errors in parentheses. *, $* *$, *** denote coefficients that differ from zero with $\mathrm{p}<0.05, \mathrm{p}<0.01$, and $\mathrm{p}<0.001$ respectively. We control for the first ten principal components of the genetic data, age, age-squared, education, self-reported health status, number of medical conditions diagnosed by a doctor, number of difficulties performing ADLs and IALDs, employment status, total number of years worked, self-assessed memory ability, and birth cohorts of both respondents and spouses, household income, number of living children, and year dummies. We cluster standard errors at the household level.

Table A12A. Log of assets and Alzheimer's Disease Polygenic Score (AD PGS) without ApoE status variants, by asset type, Tobit Models

\begin{tabular}{|c|c|c|c|c|c|c|c|}
\hline $\begin{array}{l}\text { AD PGS w/o ApoE } \\
\text { variants }\end{array}$ & $\begin{array}{l}\text { Financial } \\
\text { assets }\end{array}$ & Stocks & Cash & IRA & CD & Bonds & Other \\
\hline Respondent & $\begin{array}{c}-0.0532 * \\
(0.0246)\end{array}$ & $\begin{array}{c}-0.3127 * * \\
(0.1095)\end{array}$ & $\begin{array}{l}-0.0123 \\
(0.0220)\end{array}$ & $\begin{array}{c}-0.2863 * * \\
(0.0931)\end{array}$ & $\begin{array}{l}0.2944^{*} \\
(0.1316)\end{array}$ & $\begin{array}{l}-0.2699 \\
(0.2224)\end{array}$ & $\begin{array}{l}-0.3277^{*} \\
(0.1334)\end{array}$ \\
\hline Spouse & $\begin{array}{l}-0.0456 \\
(0.0278)\end{array}$ & $\begin{array}{l}-0.1925 \\
(0.1230)\end{array}$ & $\begin{array}{c}0.0029 \\
(0.0247)\end{array}$ & $\begin{array}{c}-0.3018^{* *} \\
(0.1039)\end{array}$ & $\begin{array}{c}0.1732 \\
(0.1488)\end{array}$ & $\begin{array}{l}-0.1500 \\
(0.2499)\end{array}$ & $\begin{array}{l}-0.3181^{*} \\
(0.1487)\end{array}$ \\
\hline Constant & $\begin{array}{l}1.9605 * \\
(0.9894)\end{array}$ & $\begin{array}{c}- \\
23.8677 * * \\
* \\
(4.5337)\end{array}$ & $\begin{array}{c}0.3627 \\
(1.1046)\end{array}$ & $\begin{array}{c}- \\
23.7702 * * \\
* \\
(3.4755)\end{array}$ & $\begin{array}{c}- \\
33.7231 * * \\
* \\
(5.8628)\end{array}$ & $\begin{array}{c}- \\
118.1736 * * * \\
(11.1699)\end{array}$ & $\begin{array}{c}-34.4849 * * * \\
(6.8919)\end{array}$ \\
\hline
\end{tabular}

Notes: N(household-year)=45,245. N(persons)=8,787. Random effects model coefficients. Robust standard errors in parentheses. *, $* *$, *** denote coefficients that differ from zero with $\mathrm{p}<0.05, \mathrm{p}<0.01$, and $\mathrm{p}<0.001$ respectively. We control for first ten principal components of the genetic data, age, age-squared, education, self-reported health status, number of medical conditions diagnosed by a 
doctor, number of difficulties with performing ADLs and IALDs, employment status, total number of years worked, self-assessed memory ability, and birth cohorts of both respondents and spouses, household income, number of living children, and year dummies. We cluster standard errors at the household level.

Table A12B. Log of assets and Alzheimer's Disease Polygenic Score (AD PGS) with ApoE status variants, by asset type, Tobit Models

\begin{tabular}{|c|c|c|c|c|c|c|c|}
\hline AD PGS & Financial assets & Stocks & Cash & IRA & CD & Bonds & Other \\
\hline Respondent & $\begin{array}{c}-0.0530^{*} \\
(0.0246)\end{array}$ & $\begin{array}{c}-0.3123^{* *} \\
(0.1095)\end{array}$ & $\begin{array}{l}-0.0123 \\
(0.0220)\end{array}$ & $\begin{array}{c}-0.2851 * * \\
(0.0931)\end{array}$ & $\begin{array}{l}0.2961^{*} \\
(0.1316)\end{array}$ & $\begin{array}{l}-0.2712 \\
(0.2224)\end{array}$ & $\begin{array}{l}-0.3292 * \\
(0.1334)\end{array}$ \\
\hline Spouse & $\begin{array}{l}-0.0453 \\
(0.0278)\end{array}$ & $\begin{array}{c}-0.1920 \\
(0.1230)\end{array}$ & $\begin{array}{c}0.0029 \\
(0.0247)\end{array}$ & $\begin{array}{c}-0.3008^{* *} \\
(0.1039)\end{array}$ & $\begin{array}{c}0.1763 \\
(0.1488)\end{array}$ & $\begin{array}{c}-0.1523 \\
(0.2499)\end{array}$ & $\begin{array}{c}-0.3184 * \\
(0.1487)\end{array}$ \\
\hline Constant & $\begin{array}{l}1.9607 \\
(0.9894)\end{array}$ & $\begin{array}{c}-23.8659 * * * \\
(4.5337)\end{array}$ & $\begin{array}{c}0.3627 \\
(1.1046)\end{array}$ & $\begin{array}{c}-23.7686 * * * \\
(3.4755)\end{array}$ & $\begin{array}{c}-33.7261 * * * \\
(5.8628)\end{array}$ & $\begin{array}{c}-118.1724 * * * \\
(11.1699)\end{array}$ & $\begin{array}{c}-34.4832 * * * \\
(6.8919)\end{array}$ \\
\hline
\end{tabular}

Notes: $\mathrm{N}($ household-year) $=45,245 . \mathrm{N}$ (persons)=8,787. Random effects model coefficients. Robust standard errors in parentheses. *, $* *$, *** denote coefficients that differ from zero with $\mathrm{p}<0.05, \mathrm{p}<0.01$, and $\mathrm{p}<0.001$ respectively. We control for first ten principal components of the genetic data, age, age-squared, education, self-reported health status, number of medical conditions diagnosed by a doctor, number of difficulties with performing ADLs and IALDs, employment status, total number of years worked, self-assessed memory ability, and birth cohorts of both respondents and spouses, household income, number of living children, and year dummies. We cluster standard errors at the household level. 
Table A13. Log of assets, Alzheimer's Disease Polygenic Score (AD PGS) without ApoE status variants, and Parental History of Memory-related Disease, by asset type

\begin{tabular}{|c|c|c|c|c|c|c|c|}
\hline AD PGS & Financial assets & Stocks & Cash & IRA & CD & Bonds & Other \\
\hline \multicolumn{8}{|l|}{ Respondent factors } \\
\hline Own AD PGS & $\begin{array}{l}-0.0430 \\
(0.0265)\end{array}$ & $\begin{array}{c}-0.1347 * * \\
(0.0487)\end{array}$ & $\begin{array}{l}-0.0050 \\
(0.0227)\end{array}$ & $\begin{array}{c}-0.1736 * * \\
(0.0533)\end{array}$ & $\begin{array}{l}0.0979 * \\
(0.0412)\end{array}$ & $\begin{array}{l}-0.0257 \\
(0.0284)\end{array}$ & $\begin{array}{l}-0.0617 \\
(0.0321)\end{array}$ \\
\hline Own Parents MRD & $\begin{array}{c}0.1862 * * \\
(0.0668)\end{array}$ & $\begin{array}{c}0.0656 \\
(0.1280)\end{array}$ & $\begin{array}{c}0.1898 * * \\
(0.0584)\end{array}$ & $\begin{array}{c}0.0855 \\
(0.1383)\end{array}$ & $\begin{array}{c}0.0486 \\
(0.1025)\end{array}$ & $\begin{array}{c}0.0744 \\
(0.0705)\end{array}$ & $\begin{array}{c}0.3803 * * * \\
(0.0933)\end{array}$ \\
\hline Own AD PGS*Parents MRD & $\begin{array}{l}-0.0802 \\
(0.0614)\end{array}$ & $\begin{array}{c}0.1306 \\
(0.1237)\end{array}$ & $\begin{array}{l}-0.0376 \\
(0.0526)\end{array}$ & $\begin{array}{c}0.1280 \\
(0.1352)\end{array}$ & $\begin{array}{l}-0.0435 \\
(0.0978)\end{array}$ & $\begin{array}{l}-0.0249 \\
(0.0648)\end{array}$ & $\begin{array}{l}-0.0577 \\
(0.0937)\end{array}$ \\
\hline \multicolumn{8}{|l|}{ Spouse factors } \\
\hline Spouse AD PGS & $\begin{array}{l}-0.0290 \\
(0.0289)\end{array}$ & $\begin{array}{l}-0.0765 \\
(0.0561)\end{array}$ & $\begin{array}{c}0.0139 \\
(0.0249)\end{array}$ & $\begin{array}{c}-0.1767 * * \\
(0.0615)\end{array}$ & $\begin{array}{c}0.0566 \\
(0.0470)\end{array}$ & $\begin{array}{l}-0.0105 \\
(0.0322)\end{array}$ & $\begin{array}{l}-0.0537 \\
(0.0370)\end{array}$ \\
\hline Spouse's Parents MRD & $\begin{array}{c}0.2999 * * * \\
(0.0674)\end{array}$ & $\begin{array}{l}0.2820^{*} \\
(0.1313)\end{array}$ & $\begin{array}{c}0.2411 * * * \\
(0.0581)\end{array}$ & $\begin{array}{l}0.2924^{*} \\
(0.1436)\end{array}$ & $\begin{array}{c}0.1573 \\
(0.1046)\end{array}$ & $\begin{array}{c}0.0629 \\
(0.0716)\end{array}$ & $\begin{array}{r}0.3608 * * * \\
(0.0951)\end{array}$ \\
\hline Spouse AD PGS*Parents MRD & $\begin{array}{c}-0.1214 \\
(0.0667)\end{array}$ & $\begin{array}{c}0.0675 \\
(0.1372)\end{array}$ & $\begin{array}{l}-0.0939 \\
(0.0561)\end{array}$ & $\begin{array}{c}0.0958 \\
(0.1518)\end{array}$ & $\begin{array}{l}-0.0640 \\
(0.1114)\end{array}$ & $\begin{array}{l}-0.0138 \\
(0.0689)\end{array}$ & $\begin{array}{l}-0.0467 \\
(0.1036)\end{array}$ \\
\hline Constant & $\begin{array}{c}2.2641 \\
(1.3468)\end{array}$ & $\begin{array}{l}-7.2613^{*} \\
(2.8188)\end{array}$ & $\begin{array}{c}1.3061 \\
(1.4919)\end{array}$ & $\begin{array}{c}-11.5189 * * * \\
(2.7839)\end{array}$ & $\begin{array}{l}-5.9038^{*} \\
(2.5724)\end{array}$ & $\begin{array}{c}-8.8971 * * * \\
(1.7882)\end{array}$ & $\begin{array}{l}-5.0191^{*} \\
(2.2338)\end{array}$ \\
\hline $\mathrm{R}^{2}$ & 0.2655 & 0.1620 & 0.1422 & 0.1479 & 0.0682 & 0.0806 & 0.0766 \\
\hline
\end{tabular}

Notes: N(household-year)=45,245. N(persons)=8,787. Random effects model coefficients. Robust standard errors in parentheses. ${ }^{*}$, $* *$, *** denote coefficients that differ from zero with $\mathrm{p}<0.05, \mathrm{p}<0.01$, and $\mathrm{p}<0.001$ respectively. We control for first ten principal components of the genetic data, age, age-squared, education, self-reported health status, number of medical conditions diagnosed by a doctor, number of difficulties with performing ADLs and IALDs, employment status, total number of years worked, self-assessed memory ability, and birth cohorts of both respondents and spouses, household income, number of living children, and year dummies. Standard errors are clustered at the household level. 
Table A14. Log of assets, Alzheimer's Disease Polygenic Score (AD PGS) without ApoE status variants, Cognition PGS, and Total Cognition Score, by asset type

\begin{tabular}{|c|c|c|c|c|c|c|c|}
\hline AD PGS & $\begin{array}{l}\text { Financial } \\
\text { assets }\end{array}$ & Stocks & Cash & IRA & CD & Bonds & Other \\
\hline \multicolumn{8}{|l|}{ Respondent factors } \\
\hline Own AD PGS & $\begin{array}{l}-0.0649 * \\
(0.0310)\end{array}$ & $\begin{array}{c}-0.1137 \\
(0.0585)\end{array}$ & $\begin{array}{l}-0.0395 \\
(0.0281)\end{array}$ & $\begin{array}{c}-0.1564 * \\
(0.0639)\end{array}$ & $\begin{array}{l}0.1313^{*} \\
(0.0523)\end{array}$ & $\begin{array}{l}-0.0032 \\
(0.0366)\end{array}$ & $\begin{array}{l}-0.0841^{*} \\
(0.0388)\end{array}$ \\
\hline Own Cognition PGS & $\begin{array}{l}-0.0336 \\
(0.0315)\end{array}$ & $\begin{array}{l}-0.0287 \\
(0.0654)\end{array}$ & $\begin{array}{l}-0.0319 \\
(0.0274)\end{array}$ & $\begin{array}{l}-0.0050 \\
(0.0677)\end{array}$ & $\begin{array}{l}-0.0353 \\
(0.0545)\end{array}$ & $\begin{array}{l}-0.0020 \\
(0.0391)\end{array}$ & $\begin{array}{l}-0.0196 \\
(0.0439)\end{array}$ \\
\hline Own AD PGS*cognition PGS & $\begin{array}{c}0.0251 \\
(0.0281)\end{array}$ & $\begin{array}{c}-0.0552 \\
(0.0597)\end{array}$ & $\begin{array}{c}0.0148 \\
(0.0240)\end{array}$ & $\begin{array}{c}-0.0205 \\
(0.0632)\end{array}$ & $\begin{array}{c}0.0602 \\
(0.0491)\end{array}$ & $\begin{array}{c}0.0482 \\
(0.0379)\end{array}$ & $\begin{array}{c}0.0059 \\
(0.0394)\end{array}$ \\
\hline Own Cognition & $\begin{array}{c}0.1048 * * * \\
(0.0227)\end{array}$ & $\begin{array}{c}0.2030 * * * \\
(0.0461)\end{array}$ & $\begin{array}{c}0.1408 * * * \\
(0.0283)\end{array}$ & $\begin{array}{c}0.1190 * * \\
(0.0425)\end{array}$ & $\begin{array}{l}0.1094^{*} \\
(0.0451)\end{array}$ & $\begin{array}{c}0.0561 \\
(0.0350)\end{array}$ & $\begin{array}{c}0.1499 * * * \\
(0.0400)\end{array}$ \\
\hline Own AD PGS*cognition & $\begin{array}{c}-0.0086 \\
(0.0206)\end{array}$ & $\begin{array}{l}-0.0087 \\
(0.0407)\end{array}$ & $\begin{array}{c}0.0179 \\
(0.0240)\end{array}$ & $\begin{array}{c}0.0213 \\
(0.0414)\end{array}$ & $\begin{array}{c}-0.0328 \\
(0.0412)\end{array}$ & $\begin{array}{c}0.0101 \\
(0.0288)\end{array}$ & $\begin{array}{l}-0.0062 \\
(0.0353)\end{array}$ \\
\hline \multicolumn{8}{|l|}{ Spouse factors } \\
\hline Spouse AD PGS & $\begin{array}{c}-0.0490 \\
(0.0339)\end{array}$ & $\begin{array}{c}-0.0671 \\
(0.0673)\end{array}$ & $\begin{array}{c}-0.0172 \\
(0.0305)\end{array}$ & $\begin{array}{c}-0.1718^{*} \\
(0.0735)\end{array}$ & $\begin{array}{c}0.0708 \\
(0.0596)\end{array}$ & $\begin{array}{c}0.0143 \\
(0.0422)\end{array}$ & $\begin{array}{l}-0.0915 * \\
(0.0446)\end{array}$ \\
\hline Spouse Cognition PGS & $\begin{array}{c}-0.0176 \\
(0.0357)\end{array}$ & $\begin{array}{c}-0.0431 \\
(0.0778)\end{array}$ & $\begin{array}{c}-0.0199 \\
(0.0309)\end{array}$ & $\begin{array}{c}-0.0238 \\
(0.0816)\end{array}$ & $\begin{array}{c}-0.0488 \\
(0.0637)\end{array}$ & $\begin{array}{c}-0.0137 \\
(0.0459)\end{array}$ & $\begin{array}{c}-0.0439 \\
(0.0520)\end{array}$ \\
\hline Spouse AD PGS*cognition PGS & $\begin{array}{c}0.0319 \\
(0.0324)\end{array}$ & $\begin{array}{c}-0.0462 \\
(0.0700)\end{array}$ & $\begin{array}{c}0.0143 \\
(0.0270)\end{array}$ & $\begin{array}{c}-0.0067 \\
(0.0726)\end{array}$ & $\begin{array}{c}0.0540 \\
(0.0569)\end{array}$ & $\begin{array}{c}0.0593 \\
(0.0427)\end{array}$ & $\begin{array}{l}-0.0081 \\
(0.0453)\end{array}$ \\
\hline Spouse Cognition & $\begin{array}{c}0.0909 * * * \\
(0.0201)\end{array}$ & $\begin{array}{c}0.1768 * * * \\
(0.0413)\end{array}$ & $\begin{array}{c}0.1079 * * * \\
(0.0253)\end{array}$ & $\begin{array}{c}0.1712 * * * \\
(0.0383)\end{array}$ & $\begin{array}{c}0.0674 \\
(0.0400)\end{array}$ & $\begin{array}{l}0.0616^{*} \\
(0.0306)\end{array}$ & $\begin{array}{c}0.1532 * * * \\
(0.0352)\end{array}$ \\
\hline Spouse AD PGS*cognition & $\begin{array}{l}-0.0130 \\
(0.0205)\end{array}$ & $\begin{array}{l}-0.0019 \\
(0.0416)\end{array}$ & $\begin{array}{c}0.0088 \\
(0.0242)\end{array}$ & $\begin{array}{c}0.0206 \\
(0.0428)\end{array}$ & $\begin{array}{l}-0.0583 \\
(0.0416)\end{array}$ & $\begin{array}{c}0.0082 \\
(0.0290)\end{array}$ & $\begin{array}{l}-0.0182 \\
(0.0368)\end{array}$ \\
\hline Constant & $\begin{array}{c}1.9984 \\
(1.8583) \\
\end{array}$ & $\begin{array}{c}-14.1309 * * * \\
(4.1760) \\
\end{array}$ & $\begin{array}{l}-0.0430 \\
(2.2911) \\
\end{array}$ & $\begin{array}{c}-13.8277^{* *} \\
(4.2296) \\
\end{array}$ & $\begin{array}{l}-4.6063 \\
(4.2210) \\
\end{array}$ & $\begin{array}{c}-11.4498^{* * *} \\
(2.9440) \\
\end{array}$ & $\begin{array}{c}-0.4234 \\
(3.6595) \\
\end{array}$ \\
\hline $\mathrm{R}^{2}$ & 0.2494 & 0.1742 & 0.1276 & 0.1404 & 0.0629 & 0.1015 & 0.0862 \\
\hline
\end{tabular}

Notes: N(household-year)=24,038. N(persons)=5,678. Random effects model coefficients. Robust standard errors in parentheses. *, $* *$, *** denote coefficients that differ from zero with $\mathrm{p}<0.05, \mathrm{p}<0.01$, and $\mathrm{p}<0.001$ respectively. We control for the first ten principal components of the genetic data, age, age-squared, education, self-reported health status, number of medical conditions diagnosed by a 
doctor, number of difficulties with performing ADLs and IALDs, employment status, total number of years worked, self-assessed memory ability, and birth cohorts of both respondents and spouses, household income, number of living children, and year dummies. Standard errors are clustered at the household level. 
Table A15. Log of assets, Alzheimer’s Disease Polygenic Score (AD PGS) without ApoE status variants, and Age, by asset type

\begin{tabular}{|c|c|c|c|c|c|c|c|}
\hline AD PGS & Financial assets & Stocks & Cash & IRA & CD & Bonds & Other \\
\hline \multicolumn{8}{|l|}{ Respondent factors } \\
\hline Own AD PGS & $\begin{array}{l}-0.0798 \\
(0.6298)\end{array}$ & $\begin{array}{c}-4.3659 * * \\
(1.4102)\end{array}$ & $\begin{array}{c}0.0119 \\
(0.7461)\end{array}$ & $\begin{array}{c}0.6238 \\
(1.3857)\end{array}$ & $\begin{array}{l}-0.9762 \\
(1.2905)\end{array}$ & $\begin{array}{l}-1.2808 \\
(0.8780)\end{array}$ & $\begin{array}{l}-2.0079 \\
(1.1145)\end{array}$ \\
\hline Own age & $\begin{array}{c}0.0344 \\
(0.0277)\end{array}$ & $\begin{array}{c}0.0366 \\
(0.0571)\end{array}$ & $\begin{array}{c}0.0070 \\
(0.0317)\end{array}$ & $\begin{array}{c}0.1927 * * * \\
(0.0552)\end{array}$ & $\begin{array}{c}0.0794 \\
(0.0527)\end{array}$ & $\begin{array}{l}0.0872^{*} \\
(0.0358)\end{array}$ & $\begin{array}{c}0.0870 \\
(0.0467)\end{array}$ \\
\hline Own AD PGS*age & $\begin{array}{c}0.0023 \\
(0.0186)\end{array}$ & $\begin{array}{c}0.1254^{* *} \\
(0.0423)\end{array}$ & $\begin{array}{c}0.0024 \\
(0.0224)\end{array}$ & $\begin{array}{l}-0.0224 \\
(0.0411)\end{array}$ & $\begin{array}{c}0.0301 \\
(0.0391)\end{array}$ & $\begin{array}{c}0.0348 \\
(0.0264)\end{array}$ & $\begin{array}{c}0.0588 \\
(0.0330)\end{array}$ \\
\hline Own age ${ }^{2}$ & $\begin{array}{l}-0.0784 \\
(0.1897)\end{array}$ & $\begin{array}{l}-0.0385 \\
(0.3993)\end{array}$ & $\begin{array}{c}0.1727 \\
(0.2243)\end{array}$ & $\begin{array}{c}-1.5541^{* * *} \\
(0.3783)\end{array}$ & $\begin{array}{l}-0.1393 \\
(0.3748)\end{array}$ & $\begin{array}{l}-0.4527 \\
(0.2561)\end{array}$ & $\begin{array}{l}-0.8202 * \\
(0.3278)\end{array}$ \\
\hline Own AD PGS*age ${ }^{2}$ & $\begin{array}{c}-0.0282 \\
(0.1346)\end{array}$ & $\begin{array}{c}-0.9053 * * \\
(0.3125)\end{array}$ & $\begin{array}{c}-0.0406 \\
(0.1651)\end{array}$ & $\begin{array}{c}0.1578 \\
(0.3006)\end{array}$ & $\begin{array}{l}-0.2071 \\
(0.2921)\end{array}$ & $\begin{array}{c}-0.2346 \\
(0.1964)\end{array}$ & $\begin{array}{c}-0.4382 \\
(0.2406)\end{array}$ \\
\hline \multicolumn{8}{|l|}{ Spouse factors } \\
\hline Spouse AD PGS & $\begin{array}{c}0.0591 \\
(0.5494)\end{array}$ & $\begin{array}{l}-1.2217 \\
(1.3037)\end{array}$ & $\begin{array}{l}-0.2642 \\
(0.6297)\end{array}$ & $\begin{array}{c}0.2609 \\
(1.2711)\end{array}$ & $\begin{array}{l}-0.7224 \\
(1.1082)\end{array}$ & $\begin{array}{l}-0.0348 \\
(0.6709)\end{array}$ & $\begin{array}{c}-0.8884 \\
(1.0524)\end{array}$ \\
\hline Spouse age & $\begin{array}{c}0.0288 \\
(0.0231)\end{array}$ & $\begin{array}{c}0.0245 \\
(0.0448)\end{array}$ & $\begin{array}{l}-0.0118 \\
(0.0234)\end{array}$ & $\begin{array}{c}0.2354 * * * \\
(0.0425)\end{array}$ & $\begin{array}{l}-0.0070 \\
(0.0376)\end{array}$ & $\begin{array}{c}0.0809 * * * \\
(0.0243)\end{array}$ & $\begin{array}{l}-0.0263 \\
(0.0354)\end{array}$ \\
\hline Spouse AD PGS*age & $\begin{array}{l}-0.0031 \\
(0.0165)\end{array}$ & $\begin{array}{c}0.0339 \\
(0.0397)\end{array}$ & $\begin{array}{c}0.0089 \\
(0.0193)\end{array}$ & $\begin{array}{l}-0.0110 \\
(0.0384)\end{array}$ & $\begin{array}{c}0.0229 \\
(0.0341)\end{array}$ & $\begin{array}{l}-0.0022 \\
(0.0209)\end{array}$ & $\begin{array}{c}0.0290 \\
(0.0317)\end{array}$ \\
\hline Spouse age ${ }^{2}$ & $\begin{array}{l}-0.0649 \\
(0.1584)\end{array}$ & $\begin{array}{c}0.1109 \\
(0.3168)\end{array}$ & $\begin{array}{c}0.1879 \\
(0.1653)\end{array}$ & $\begin{array}{c}-1.8051^{* * *} \\
(0.2930)\end{array}$ & $\begin{array}{c}0.4579 \\
(0.2714)\end{array}$ & $\begin{array}{l}-0.3908 * \\
(0.1793)\end{array}$ & $\begin{array}{c}0.1322 \\
(0.2495)\end{array}$ \\
\hline Spouse AD PGS*age ${ }^{2}$ & $\begin{array}{c}0.0221 \\
(0.1215)\end{array}$ & $\begin{array}{l}-0.2418 \\
(0.2979)\end{array}$ & $\begin{array}{l}-0.0729 \\
(0.1462)\end{array}$ & $\begin{array}{c}0.0688 \\
(0.2853)\end{array}$ & $\begin{array}{l}-0.1671 \\
(0.2595)\end{array}$ & $\begin{array}{c}0.0379 \\
(0.1599)\end{array}$ & $\begin{array}{l}-0.2443 \\
(0.2352)\end{array}$ \\
\hline Constant & $\begin{array}{c}2.6161 \\
(1.3474)\end{array}$ & $\begin{array}{c}-7.2678 * * \\
(2.8102)\end{array}$ & $\begin{array}{c}1.6315 \\
(1.4927)\end{array}$ & $\begin{array}{c}-11.2457 * * * \\
(2.7820)\end{array}$ & $\begin{array}{l}-5.8646^{*} \\
(2.5690)\end{array}$ & $\begin{array}{c}-8.8271 * * * \\
(1.7821)\end{array}$ & $\begin{array}{l}-4.5613^{*} \\
(2.2339)\end{array}$ \\
\hline Own AD PGS joint Chi²(3) & 5.77 & $16.30 * *$ & 3.14 & $9.71^{*}$ & 6.37 & 6.09 & $9.28 *$ \\
\hline Spouse AD PGS joint $\mathrm{Chi}^{2}(3)$ & 3.40 & 2.37 & 0.39 & 7.70 & 1.63 & 1.96 & 5.77 \\
\hline $\mathrm{R}^{2}$ & 0.2634 & 0.1615 & 0.1412 & 0.1469 & 0.0681 & 0.0806 & 0.0746 \\
\hline
\end{tabular}

Notes: N(household-year)=45,245. N(persons)=8,787. Random effects model coefficients. Robust standard errors in parentheses. Agesquared is divided by $1,000 . *$, **, *** denote coefficients that differ from zero with $\mathrm{p}<0.05, \mathrm{p}<0.01$, and $\mathrm{p}<0.001$ respectively. We control for the first ten principal components of the genetic data, age-squared, education, self-reported health status, number of 
medical conditions diagnosed by a doctor, number of difficulties with performing ADLs and IALDs, employment status, total number of years worked, self-assessed memory ability, and birth cohorts of both respondents and spouses, household income, number of living children, and year dummies. We cluster standard errors at the household level. 
Table A16. Log of assets, Alzheimer’s Disease Polygenic Score (AD PGS) without ApoE status variants, and Self-rated Memory, by asset type

\begin{tabular}{|c|c|c|c|c|c|c|c|}
\hline AD PGS & $\begin{array}{l}\text { Financial } \\
\text { assets }\end{array}$ & Stocks & Cash & IRA & CD & Bonds & Other \\
\hline \multicolumn{8}{|l|}{ Respondent factors } \\
\hline Own AD PGS & $\begin{array}{l}-0.0551^{*} \\
(0.0244)\end{array}$ & $\begin{array}{l}-0.1150 * \\
(0.0450)\end{array}$ & $\begin{array}{l}-0.0110 \\
(0.0290)\end{array}$ & $\begin{array}{c}-0.1516 * * \\
(0.0493)\end{array}$ & $\begin{array}{l}0.0914^{*} \\
(0.0377)\end{array}$ & $\begin{array}{l}-0.0292 \\
(0.0259)\end{array}$ & $\begin{array}{l}-0.0696^{*} \\
(0.0302)\end{array}$ \\
\hline Own self-rated memory & $\begin{array}{c}0.0050 \\
(0.0143)\end{array}$ & $\begin{array}{l}-0.0001 \\
(0.0278)\end{array}$ & $\begin{array}{l}-0.0022 \\
(0.0172)\end{array}$ & $\begin{array}{c}0.0073 \\
(0.0268)\end{array}$ & $\begin{array}{c}0.0033 \\
(0.0264)\end{array}$ & $\begin{array}{l}-0.0187 \\
(0.0193)\end{array}$ & $\begin{array}{l}0.0687 * * \\
(0.0255)\end{array}$ \\
\hline $\begin{array}{l}\text { Own AD PGS*self-rated } \\
\text { memory }\end{array}$ & $\begin{array}{c}0.0031 \\
(0.0143)\end{array}$ & $\begin{array}{c}0.0081 \\
(0.0263)\end{array}$ & $\begin{array}{c}0.0054 \\
(0.0163)\end{array}$ & $\begin{array}{l}-0.0170 \\
(0.0261)\end{array}$ & $\begin{array}{l}-0.0133 \\
(0.0254)\end{array}$ & $\begin{array}{l}-0.0029 \\
(0.0191)\end{array}$ & $\begin{array}{c}0.0032 \\
(0.0244)\end{array}$ \\
\hline \multicolumn{8}{|l|}{ Spouse factors } \\
\hline Spouse AD PGS & $\begin{array}{l}-0.0483 \\
(0.0265)\end{array}$ & $\begin{array}{l}-0.0624 \\
(0.0519)\end{array}$ & $\begin{array}{l}-0.0012 \\
(0.0228)\end{array}$ & $\begin{array}{l}-0.1571 \\
(0.0571)\end{array}$ & $\begin{array}{c}0.0475 \\
(0.0429)\end{array}$ & $\begin{array}{l}-0.0123 \\
(0.0291)\end{array}$ & $\begin{array}{l}-0.0604 \\
(0.0348)\end{array}$ \\
\hline Spouse self-rated memory & $\begin{array}{c}0.0021 \\
(0.0138)\end{array}$ & $\begin{array}{l}-0.0097 \\
(0.0270)\end{array}$ & $\begin{array}{c}0.0120 \\
(0.0166)\end{array}$ & $\begin{array}{c}0.0148 \\
(0.0260)\end{array}$ & $\begin{array}{l}-0.0067 \\
(0.0253)\end{array}$ & $\begin{array}{l}-0.0126 \\
(0.0182)\end{array}$ & $\begin{array}{l}0.0686^{* *} \\
(0.0243)\end{array}$ \\
\hline $\begin{array}{l}\text { Spouse AD PGS*self-rated } \\
\text { memory }\end{array}$ & $\begin{array}{c}0.0025 \\
(0.0149)\end{array}$ & $\begin{array}{c}0.0159 \\
(0.0287)\end{array}$ & $\begin{array}{c}0.0085 \\
(0.0175)\end{array}$ & $\begin{array}{l}-0.0275 \\
(0.0289)\end{array}$ & $\begin{array}{l}-0.0181 \\
(0.0272)\end{array}$ & $\begin{array}{l}-0.0106 \\
(0.0202)\end{array}$ & $\begin{array}{l}-0.0109 \\
(0.0267)\end{array}$ \\
\hline Constant & $\begin{array}{c}2.6075 \\
(1.3444)\end{array}$ & $\begin{array}{l}-7.0802 \\
(2.8142)\end{array}$ & $\begin{array}{c}1.6372 \\
(1.4907)\end{array}$ & $\begin{array}{c}- \\
11.2811^{* *} \\
* \\
(2.7802) \\
\end{array}$ & $\begin{array}{l}-5.7822 \\
(2.5664)\end{array}$ & $\begin{array}{c}- \\
8.7871^{* * *} \\
(1.7811)\end{array}$ & $\begin{array}{c}-4.4445^{*} \\
(2.2363)\end{array}$ \\
\hline$\overline{\mathrm{R}^{2}}$ & 0.2634 & 0.1617 & 0.1411 & 0.1472 & 0.0680 & 0.0805 & 0.0745 \\
\hline \multicolumn{8}{|c|}{$\begin{array}{l}\text { Notes: } \mathrm{N}(\text { household-year) }=45,245 . \mathrm{N} \text { (persons) }=8,787 . \text { Random effects model coefficients. Robust standard errors in parentheses. } * \text {, } \\
* *, * * * \text { denote coefficients that differ from zero with } \mathrm{p}<0.05, \mathrm{p}<0.01 \text {, and } \mathrm{p}<0.001 \text { respectively. We control for first ten principal } \\
\text { components of the genetic data, age, age-squared, education, self-reported health status, number of medical conditions diagnosed by a } \\
\text { doctor, number of difficulties with performing ADLs and IALDs, employment status, total number of years worked, and birth cohorts } \\
\text { of both respondents and spouses, household income, number of living children, and year dummies. Standard errors are clustered at the } \\
\text { household level. }\end{array}$} \\
\hline
\end{tabular}


Table A17. Log of assets, Alzheimer’s Disease Polygenic Score (AD PGS) without ApoE status variants, and Risk Aversion, by asset type

\begin{tabular}{|c|c|c|c|c|c|c|c|}
\hline AD PGS & Financial assets & Stocks & Cash & IRA & CD & Bonds & Other \\
\hline \multicolumn{8}{|l|}{ "Respondent factors } \\
\hline Own AD PGS & $\begin{array}{l}-0.0415 \\
(0.0315)\end{array}$ & $\begin{array}{c}-0.1002 \\
(0.0580)\end{array}$ & $\begin{array}{c}0.0141 \\
(0.0272)\end{array}$ & $\begin{array}{c}-0.1362 * \\
(0.0638)\end{array}$ & $\begin{array}{c}0.0732 \\
(0.0477)\end{array}$ & $\begin{array}{c}-0.0356 \\
(0.0313)\end{array}$ & $\begin{array}{c}-0.0813^{*} \\
(0.0402)\end{array}$ \\
\hline Own Risk aversion & $\begin{array}{c}-0.0650 \\
(0.0434)\end{array}$ & $\begin{array}{c}-0.0463 \\
(0.0924)\end{array}$ & $\begin{array}{c}-0.0586 \\
(0.0463)\end{array}$ & $\begin{array}{c}-0.0516 \\
(0.0975)\end{array}$ & $\begin{array}{c}0.0926 \\
(0.0790)\end{array}$ & $\begin{array}{c}-0.0334 \\
(0.0533)\end{array}$ & $\begin{array}{c}-0.1206 \\
(0.0785)\end{array}$ \\
\hline \multicolumn{8}{|l|}{ Spouse factors } \\
\hline Spouse AD PGS & $\begin{array}{c}-0.0292 \\
(0.0332)\end{array}$ & $\begin{array}{c}-0.0635 \\
(0.0649)\end{array}$ & $\begin{array}{c}0.0116 \\
(0.0288)\end{array}$ & $\begin{array}{c}-0.1028 \\
(0.0714)\end{array}$ & $\begin{array}{c}0.0850 \\
(0.0536)\end{array}$ & $\begin{array}{c}-0.0210 \\
(0.0347)\end{array}$ & $\begin{array}{c}-0.0440 \\
(0.0453)\end{array}$ \\
\hline Spouse Risk aversion & $\begin{array}{c}0.0186 \\
(0.0439)\end{array}$ & $\begin{array}{l}-0.1089 \\
(0.0969)\end{array}$ & $\begin{array}{c}0.0199 \\
(0.0469)\end{array}$ & $\begin{array}{c}0.0842 \\
(0.0999)\end{array}$ & $\begin{array}{c}0.1095 \\
(0.0817)\end{array}$ & $\begin{array}{c}0.0281 \\
(0.0535)\end{array}$ & $\begin{array}{c}-0.0162 \\
(0.0790)\end{array}$ \\
\hline Constant & $\begin{array}{l}4.2790 * \\
(2.0276)\end{array}$ & $\begin{array}{l}-7.2293 \\
(4.0974)\end{array}$ & $\begin{array}{c}3.6486 \\
(2.2353)\end{array}$ & $\begin{array}{c}-11.2007^{* *} \\
(4.0116)\end{array}$ & $\begin{array}{l}-5.8091 \\
(3.7810)\end{array}$ & $\begin{array}{c}-8.0170^{* *} \\
(2.5299)\end{array}$ & $\begin{array}{l}-2.8662 \\
(3.2241)\end{array}$ \\
\hline $\mathrm{R}^{2}$ & 0.2851 & 0.1603 & 0.1566 & 0.1589 & 0.0637 & 0.0679 & 0.0770 \\
\hline
\end{tabular}


Table A18. Log of assets, Alzheimer’s Disease Polygenic Score (AD PGS) without ApoE status variants, and Planning Horizon, by asset type

\begin{tabular}{|c|c|c|c|c|c|c|c|}
\hline AD PGS & Financial assets & Stocks & Cash & IRA & CD & Bonds & Other \\
\hline \multicolumn{8}{|l|}{ Respondent factors } \\
\hline Own AD PGS & $\begin{array}{l}-0.0561^{*} \\
(0.0255)\end{array}$ & $\begin{array}{l}-0.1044^{*} \\
(0.0494)\end{array}$ & $\begin{array}{l}-0.0105 \\
(0.0224)\end{array}$ & $\begin{array}{c}-0.1465 * * \\
(0.0525)\end{array}$ & $\begin{array}{c}0.1143^{* *} \\
(0.0417)\end{array}$ & $\begin{array}{l}-0.0285 \\
(0.0284)\end{array}$ & $\begin{array}{l}-0.0662 \\
(0.0356)\end{array}$ \\
\hline \multicolumn{8}{|l|}{ Own planning horizon } \\
\hline Next year & $\begin{array}{c}0.2604 * * * \\
(0.0622)\end{array}$ & $\begin{array}{c}0.0080 \\
(0.1183)\end{array}$ & $\begin{array}{c}0.2417 * * * \\
(0.0719)\end{array}$ & $\begin{array}{c}0.1461 \\
(0.1214)\end{array}$ & $\begin{array}{c}0.0932 \\
(0.1099)\end{array}$ & $\begin{array}{l}-0.1057 \\
(0.0689)\end{array}$ & $\begin{array}{c}0.2688 * * \\
(0.1006)\end{array}$ \\
\hline Next few years & $\begin{array}{c}0.3947 * * * \\
(0.0544)\end{array}$ & $\begin{array}{c}0.4235^{* * * *} \\
(0.1026)\end{array}$ & $\begin{array}{c}0.3724 * * * \\
(0.0610)\end{array}$ & $\begin{array}{c}0.3930 * * * \\
(0.1021)\end{array}$ & $\begin{array}{c}0.2858 * * \\
(0.0926)\end{array}$ & $\begin{array}{c}0.0038 \\
(0.0593)\end{array}$ & $\begin{array}{l}0.2101^{*} \\
(0.0838)\end{array}$ \\
\hline Next 5-10 years & $\begin{array}{c}0.4215 * * * \\
(0.0542)\end{array}$ & $\begin{array}{c}0.4303 * * * \\
(0.1029)\end{array}$ & $\begin{array}{c}0.4719 * * * \\
(0.0598)\end{array}$ & $\begin{array}{c}0.5276^{* * * *} \\
(0.1009)\end{array}$ & $\begin{array}{c}0.2528 * * \\
(0.0924)\end{array}$ & $\begin{array}{c}0.0520 \\
(0.0592)\end{array}$ & $\begin{array}{c}0.3000 * * * \\
(0.0846)\end{array}$ \\
\hline Longer than 10 years & $\begin{array}{c}0.4233 * * * \\
(0.0619)\end{array}$ & $\begin{array}{c}0.5462 * * * \\
(0.1323)\end{array}$ & $\begin{array}{c}0.3932 * * * \\
(0.0720)\end{array}$ & $\begin{array}{c}0.5172 * * * \\
(0.1192)\end{array}$ & $\begin{array}{c}0.3112 * * \\
(0.1149)\end{array}$ & $\begin{array}{c}0.1182 \\
(0.0786)\end{array}$ & $\begin{array}{c}0.4051 * * * \\
(0.1118)\end{array}$ \\
\hline \multicolumn{8}{|l|}{ Spouse factors } \\
\hline Spouse AD PGS & $\begin{array}{l}-0.0478 \\
(0.0270)\end{array}$ & $\begin{array}{l}-0.0549 \\
(0.0552)\end{array}$ & $\begin{array}{c}0.0044 \\
(0.0241)\end{array}$ & $\begin{array}{l}-0.1405^{*} \\
(0.0585)\end{array}$ & $\begin{array}{c}0.0841 \\
(0.0467)\end{array}$ & $\begin{array}{l}-0.0133 \\
(0.0316)\end{array}$ & $\begin{array}{c}-0.0529 \\
(0.0394)\end{array}$ \\
\hline \multicolumn{8}{|l|}{ Spouse planning horizon } \\
\hline Next year & $\begin{array}{c}0.2460 * * * \\
(0.0631)\end{array}$ & $\begin{array}{c}-0.0362 \\
(0.1171)\end{array}$ & $\begin{array}{c}0.2219 * * \\
(0.0704)\end{array}$ & $\begin{array}{c}0.1755 \\
(0.1187)\end{array}$ & $\begin{array}{c}0.0841 \\
(0.0467)\end{array}$ & $\begin{array}{l}-0.0946 \\
(0.0671)\end{array}$ & $\begin{array}{l}0.2532 * \\
(0.0982)\end{array}$ \\
\hline Next few years & $\begin{array}{c}0.3342 * * * \\
(0.0539)\end{array}$ & $\begin{array}{c}0.2863 * * \\
(0.1013)\end{array}$ & $\begin{array}{c}0.3272 * * * \\
(0.0587)\end{array}$ & $\begin{array}{c}0.3855^{* * * *} \\
(0.0991)\end{array}$ & $\begin{array}{c}0.2385^{* *} \\
(0.0920)\end{array}$ & $\begin{array}{c}0.0051 \\
(0.0573)\end{array}$ & $\begin{array}{l}0.1922 * \\
(0.0832)\end{array}$ \\
\hline Next 5-10 years & $\begin{array}{c}0.3706 * * * \\
(0.0541)\end{array}$ & $\begin{array}{c}0.3409 * * * \\
(0.1031)\end{array}$ & $\begin{array}{c}0.3723 * * * \\
(0.0583)\end{array}$ & $\begin{array}{c}0.5707 * * * \\
(0.0980)\end{array}$ & $\begin{array}{l}0.2369 * \\
(0.0922)\end{array}$ & $\begin{array}{c}0.0542 \\
(0.0568)\end{array}$ & $\begin{array}{c}0.2392 * * \\
(0.0834)\end{array}$ \\
\hline Longer than 10 years & $\begin{array}{c}0.3944 * * * \\
(0.0607)\end{array}$ & $\begin{array}{c}0.4634 * * * \\
(0.1279)\end{array}$ & $\begin{array}{c}0.3182 * * * \\
(0.0714)\end{array}$ & $\begin{array}{c}0.5450 * * * \\
(0.1167)\end{array}$ & $\begin{array}{c}0.3719 * * \\
(0.1128)\end{array}$ & $\begin{array}{l}0.1603^{*} \\
(0.0761)\end{array}$ & $\begin{array}{c}0.3496 * * \\
(0.1091)\end{array}$ \\
\hline Constant & $\begin{array}{c}0.4198 \\
(1.7445)\end{array}$ & $\begin{array}{c}-14.5363^{* *} \\
(5.0323)\end{array}$ & $\begin{array}{c}1.9424 \\
(1.8987)\end{array}$ & $\begin{array}{c}-20.4079 * * * \\
(3.8915)\end{array}$ & $\begin{array}{l}-5.0249 \\
(3.4640)\end{array}$ & $\begin{array}{c}-11.8189 * * * \\
(3.1360)\end{array}$ & $\begin{array}{c}-10.7422 * * * \\
(3.2450)\end{array}$ \\
\hline$\overline{\mathrm{R}^{2}}$ & 0.2993 & 0.1691 & 0.1674 & 0.1661 & 0.0786 & 0.0803 & 0.0816 \\
\hline
\end{tabular}

Notes: N(household-year)=27,558. N(persons)=7,900. Random effects model coefficients. Robust standard errors in parentheses. $*$, $* *$, *** denote coefficients that differ from zero with $\mathrm{p}<0.05, \mathrm{p}<0.01$, and $\mathrm{p}<0.001$ respectively. We control for the first ten principal 
components of the genetic data, age, age-squared, education, self-reported health status, number of medical conditions diagnosed by a doctor, number of difficulties with performing ADLs and IALDs, employment status, total number of years worked, self-assessed memory ability, and birth cohorts of both respondents and spouses, household income, number of living children, and year dummies. We cluster standard errors at the household level. 